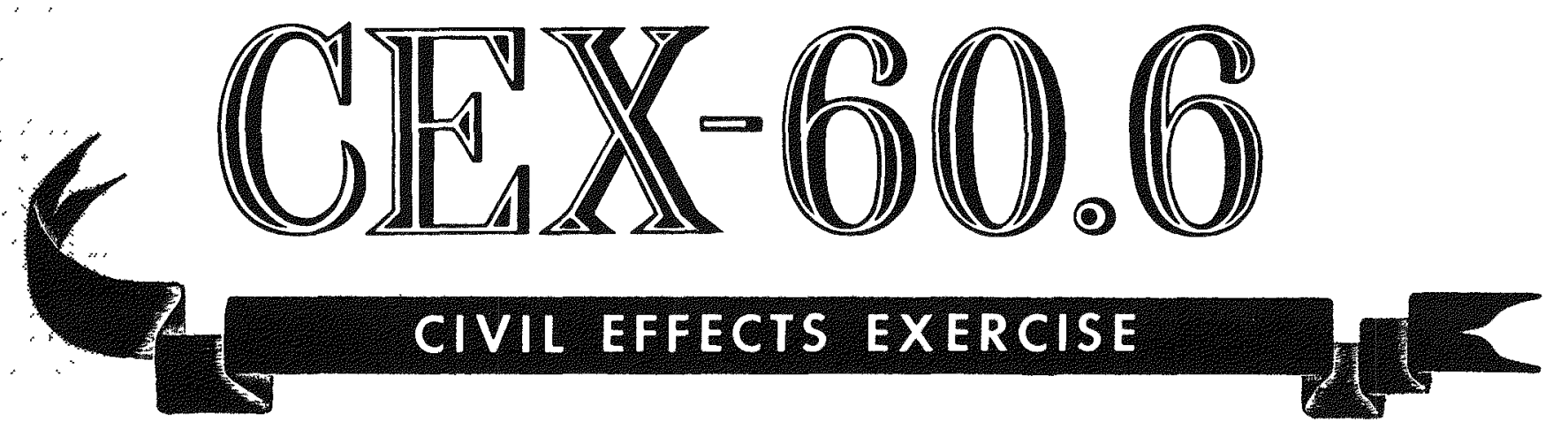

EXPERIMENTAL EVALUATION OF THE RADIATION PROTECTION PROVIDED BY AN EARTH-COVERED SHELTER

Z. Burson and $\mathrm{H}$. Borella 


\section{NOTICE}

This report is published in the interest of providing information which may prove of value to the reader in his study of effects data derived principally from nuclear weapons tests and from experiments designed to duplicate various characteristics of nuclear weapons.

This document is based on information available at the time of preparation which may have subsequently been expanded and re-evaluated. Also, in preparing this report for publication, some classified material may have been removed. Users are cautioned to avoid interpretations and conclusions based on unknown or incomplete data.

PRINTED IN USA

Price $\$ 1.00$. Available from the Office of Technical Services, Department of Commerce. Washington 25, D. C. 


\section{DISCLAIMER}

This report was prepared as an account of work sponsored by an agency of the United States Government. Neither the United States Government nor any agency Thereof, nor any of their employees, makes any warranty, express or implied, or assumes any legal liability or responsibility for the accuracy, completeness, or usefulness of any information, apparatus, product, or process disclosed, or represents that its use would not infringe privately owned rights. Reference herein to any specific commercial product, process, or service by trade name, trademark, manufacturer, or otherwise does not necessarily constitute or imply its endorsement, recommendation, or favoring by the United States Government or any agency thereof. The views and opinions of authors expressed herein do not necessarily state or reflect those of the United States Government or any agency thereof. 


\section{DISCLAIMER}

Portions of this document may be illegible in electronic image products. Images are produced from the best available original document. 


\title{
EXPERIMENTAL EVALUATION OF THE RADIATION PROTECTION PROVIDED BY AN EARTH-COVERED SHELTER
}

\author{
By \\ Z. Burson and H. Borella
}

Approved by: R. L. CORSBIE
Director
Civil Effects Test Operations
U. S. Atomic Energy Commission

Edgerton, Germeshausen \& Grier, Inc.

Santa Barbara Operations

Santa Barbara, California

April 1961 


\section{TECHNICAL PARTICIPANTS}

H. M. Borella, Edgerton, Germeshausen \& Grier, Inc., Santa Barbara, Calif.

J. T. Brashears, Edgerton, Germeshausen \& Grier, Inc., Las Vegas, Nev.

L. E. Burpee, Edgerton, Germeshausen \& Grier, Inc., Santa Barbara, Calif.

Z. G. Burson, Edgerton, Germeshausen \& Grier, Inc., Las Vegas, Nev.

William Lee, Edgerton, Germeshausen \& Grier, Inc., Santa Barbara, Calif.

E. J. Martchenke, Edgerton, Germeshausen \& Grier, Inc., Santa Barbara, Calif. 


\begin{abstract}
A study was undertaken to determine the protection against fallout radiation provided by an earth-covered shelter. The study indicated that the shelter offered excellent protection from fallout radiation deposited on and around the shelter. This study also added additional data to the research in radiation shielding provided by various structures which is being conducted by the Civil Effects Test Operations, Division of Biology and Medicine, U. S. Atomic Energy Commission.

A fallout radiation field was simulated by pumping, at constant speed, a sealed $\mathrm{Co}^{60}$ source through a long length of tubing which was evenly distributed over an area. Radiation measurements were made inside the shelter by dose-integrating ionization chambers.

In general, the results indicated that the protection factor (ratio of the open-field exposure dose rate to the exposure dose rate in the structure) was approximately 5000 in the center of the shelter, increasing to 10,000 to 15,000 along the sides, and decreasing to about 3000 near the ends. Directly below vents the protection factor was found to be approximately 2500 at the 3-ft level.

The shelter was a half-round corrugated-steel structure covered by a minimum of approximately $2 \mathrm{ft}$ of earth on the top and 5 to $7 \mathrm{ft}$ of earth on the sides.
\end{abstract}




\section{PREFACE}

The Atomic Energy Commission was requested by the Director of the Office of Civil and Defense Mobilization, the agency responsible for national civil defense, to assist in determining the radiation protection provided by an earth-covered shelter. This report contains the results of experimental measurements that were conducted during September and October 1960. The data contained in this report add to a growing body of experimental information on the radiation protection factors of a variety of structures. The measurements were made by Edgerton, Germeshausen \& Grier, Inc., for the Civil Effects Test Operations, Division of Biology and Medicine, USAEC. 


\section{ACKNOWLEDGMENTS}

The authors wish to express their appreciation to the participants, whose untiring efforts made possible the successful completion of the experiment. Also, the authors gratefully acknowledge the many valuable contributions made by each of the following:

R. L. Corsbie, L. J. Deal, and members of the Civil Effects Test Operations staff for over-all support.

J. E. Miller and other members of the Office of Civil and Defense Mobilization, Region 3, staff. 
- 


\section{CONTENTS}

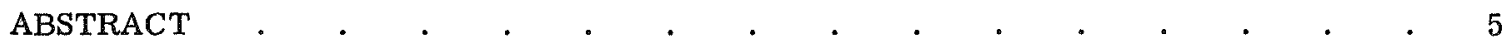

PREFACE . . . . . . . . . . . . . . . . . . . . . . . . . . 6

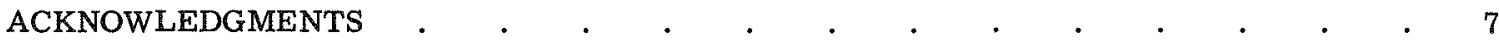

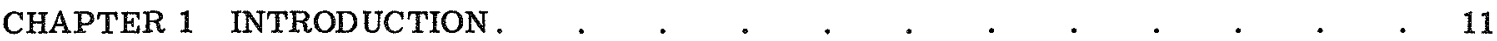

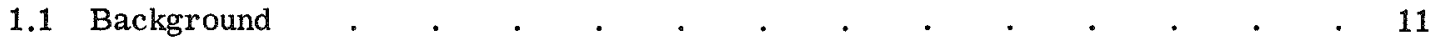

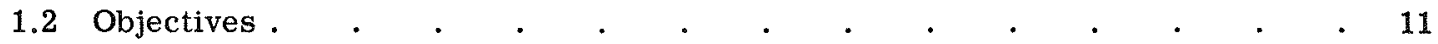

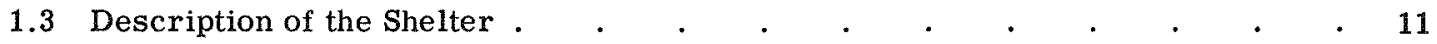

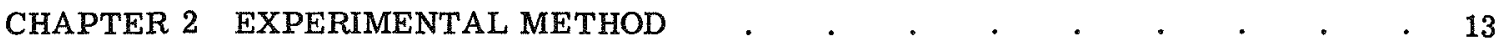

2.1 General Description . . . . . . . . . . . . . 13

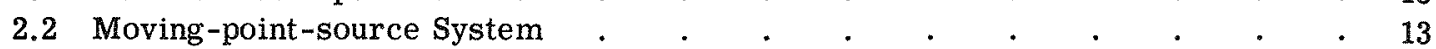

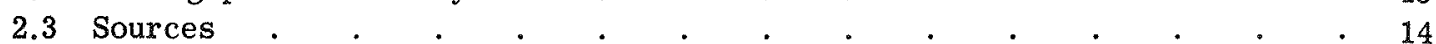

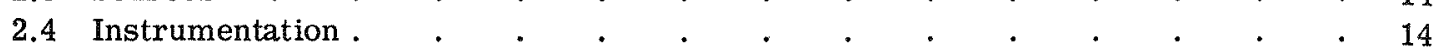

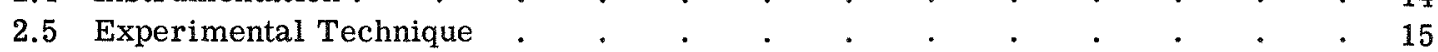

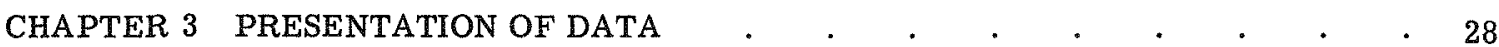

3.1 Dose Measurements . . . . . . . . . . . . . . . 28

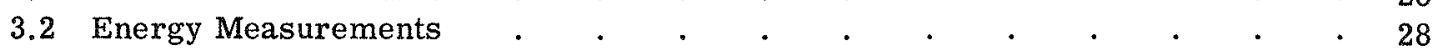

3.3 Point-source Measurements . . . . . . . . . . . . . $\quad$. 28

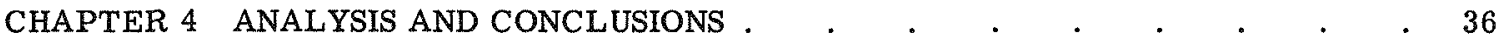

4.1 General . . . . . . . . . . . . . . . . . . 36

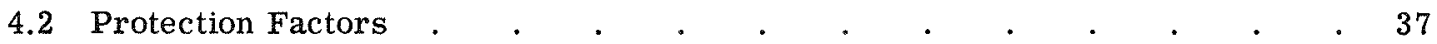

4.3 Energy Measurements . . . . . . . . . . . . . . . . . . $\quad . \quad 37$

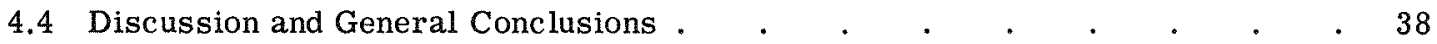

APPENDIX A RADIOLOGICAL-SAFETY OPERATIONS . . . . . . . . . $\quad$. 41

APPENDIX B SAMPLE OF DATA, ANALYSIS, AND EVALUATION $\quad \cdot \quad$ • $\quad$. $\quad 43$

\section{ILLUSTRATIONS}

\section{CHAPTER 1 INTRODUCTION}

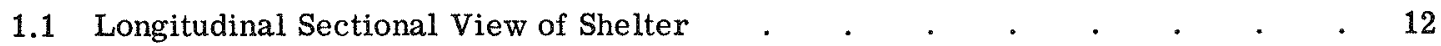

1.2 South End (Main Entrance) Elevation of Shelter . . . . . . . . $\quad$. 12 


\section{ILLUSTRATIONS (Continued)}

\section{CHAPTER 2 EXPERIMENTAL METHOD}

2.1 Caisson Trailer. . . . . . . . . . . . . . . 16

2.2 Laboratory Truck . . . . . . . . . . . . . . . . 16

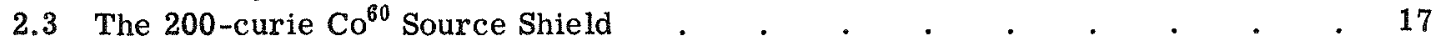

2.4 Interior of Source Truck Showing Shields and Pumping System . . . . . 17

2.5 Emergency Hand Pump . . . . . . . . . . . . . . 18

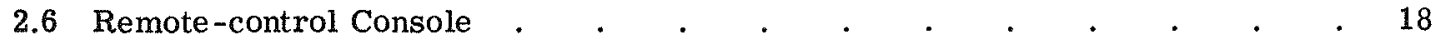

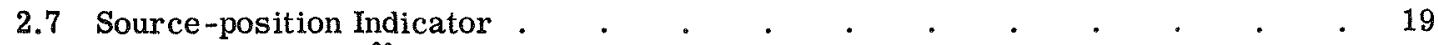

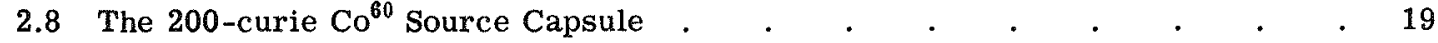

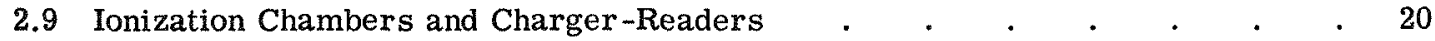

2.10 Calibration Curve for Victoreen Model 239 Ionization Chambers . . . . $\quad 21$

2.11 Energy Response of Victoreen Model 239 Ionization Chamber . . . . . 22

2.12 The 256-channel Analyzer and Associated Equipment . . . . . . . 23

2.13 Tubing Layout at Shelter . . . . . . . . . . . . . . $\quad 24$

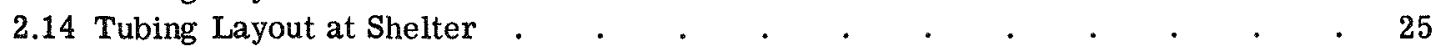

2.15 Tubing Layout at Shelter . . . . . . . . . . . . . . 25

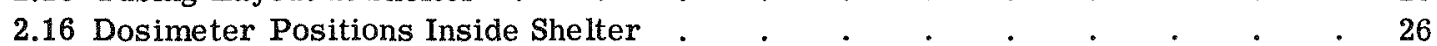

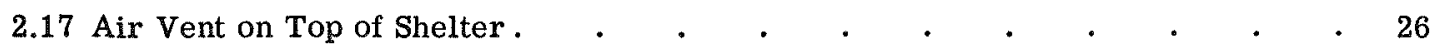

2.18 Floor Plan of Shelter Showing Crystal Assembly (A, B, C) and
Dosimeter (X) Positions . . . . . . . . . . 27

\section{CHAPTER 3 PRESENTATION OF DATA}

3.1 Pulse-height Distribution from $\mathrm{Co}^{60}$ Standard $\quad$. $\quad$. 30

3.2 Pulse-height Distribution 3 Ft Above Rectangular Area Source $\quad$. . . . 31

3.3 Pulse-height Distribution at Position A from 196-curie $\mathrm{Co}^{60}$ Source . . . . 32

3.4 Pulse-height Distribution at Position B from 196-curie $\mathrm{Co}^{60}$ Source . . . . 33

3.5 Pulse-height Distribution at Position B from 16.3-curie $\mathrm{Co}^{60}$ Source . . . 34

3.6 Pulse-height Distribution at Position $\mathrm{C}$ from 16.3-curie $\mathrm{Co}^{60}$ Source . . . $\quad 35$

\section{CHAPTER 4 ANALYSIS AND CONCLUSIONS}

4.1 Protection Factors Plotted on Floor Plan at Different Heights Above Floor

\section{TABLES}

\section{CHAPTER 3 PRESENTATION OF DATA}

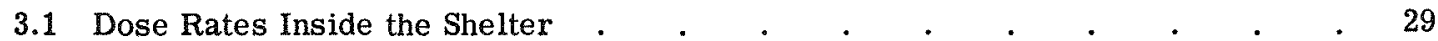

3.2 Data from Point Source Placed on Vent . . . . . . . . . . $\quad$. 29

CHAPTER 4 ANALYSIS AND CONCLUSIONS

4.1 Protection Factors at Positions in the Shelter . . . . . . . . . . 39

APPENDIX B SAMPLE OF DATA, ANALYSIS, AND EVALUATION

B.1 Correction and Normalization of Data 


\section{Chapter 1}

\section{INTRODUCTION}

\subsection{BACKGROUND}

Although theoretical estimates can provide, on a statistical basis, an estimate of the protection afforded by various types of structures against radiation from fallout, they do not provide specific information concerning the protection of a particular building. Recognizing the need for protection against the hazards of nuclear attacks or nuclear accidents, the Civil Effects Test Operations, Division of Biology and Medicine, of the Atomic Energy Commission has conducted a series of measurements to evaluate the protection characteristics of various structures. $^{1-4}$ The measurements made during this experiment were part of the continuing effort to meet this need.

\subsection{OBJECTIVES}

The objectives of the experiment were as follows:

1. To determine the radiation protection throughout a half-round corrugated-steel earthcovered shelter

2. To determine the pulse-height distribution of the radiation inside the shelter from a plane radiation source on and around the shelter

\subsection{DESCRIPTION OF THE SHELTER}

The shelter, $20 \mathrm{ft}$ wide, $100 \mathrm{ft}$ long, and $10 \mathrm{ft}$ high, was part of a line of preengineered and packaged fallout shelters fabricated from 2 -ft-wide sheets of galvanized steel which were vinyl coated on the interior side. The steel sheets were corrugated and curved to form self-supporting arches secured by simple nut-and-bolt fasteners. The entire shelter was covered to a minimum thickness of approximately $2 \mathrm{ft}$ of earth (Figs. 1.1 and 1.2).

\section{REFERENCES}

1. J. A. Auxier et al., Experimental Evaluation of the Radiation Protection Afforded by Residential Structures Against Distributed Sources, USAEC Report CEX-58.1, January 1959.

2. J. F. Batter, Jr., et al., An Experimental Evaluation of the Radiation Protection Afforded by a Large Modern Concrete Office Building, USAEC Report CEX-59.1, January 1960.

3. J. A. Auxier and T. D. Strickler, Experimental Evaluation of the Radiation Protection Afforded by Typical Oak Ridge Homes Against Distributed Sources, USAEC Report CEX-59.13, April 1960.

4. H. M. Borella et al., Evaluation of the Fallout Protection Afforded by Brookhaven National Laboratory Medical Research Center, USAEC Report CEX-60.1, February 1961. 


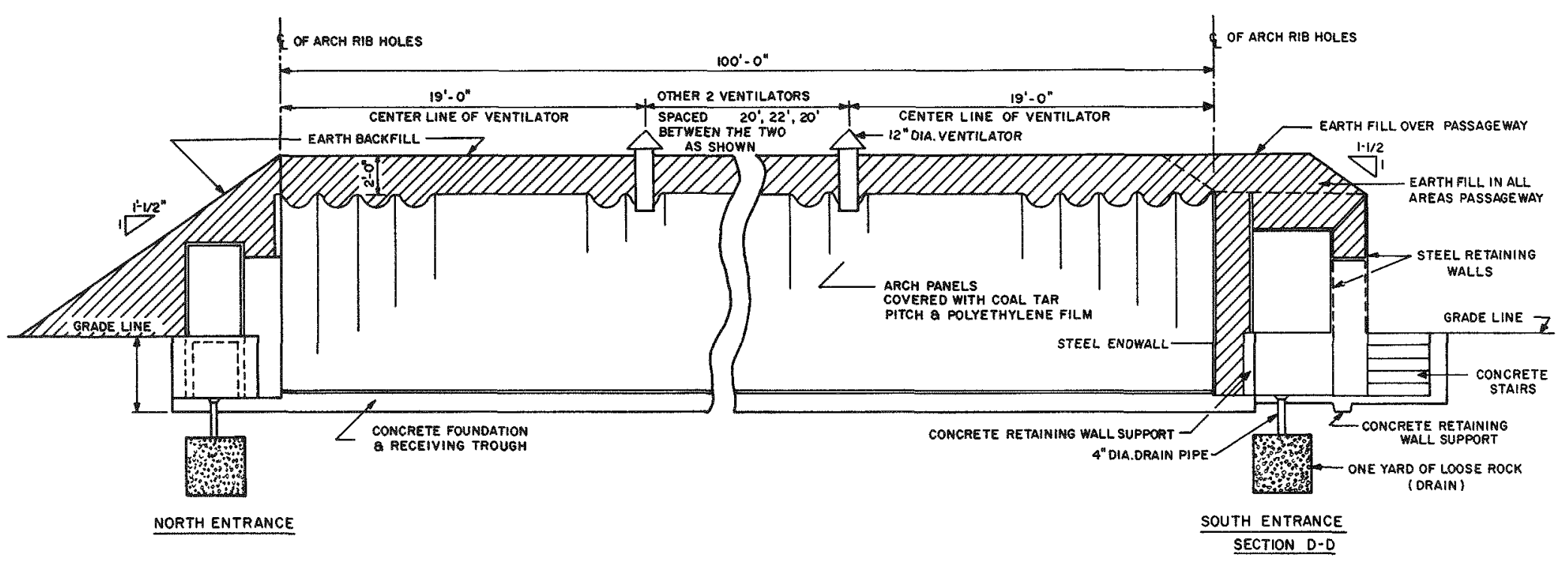

Fig. 1.1-Longitudinal sectional view of shelter.

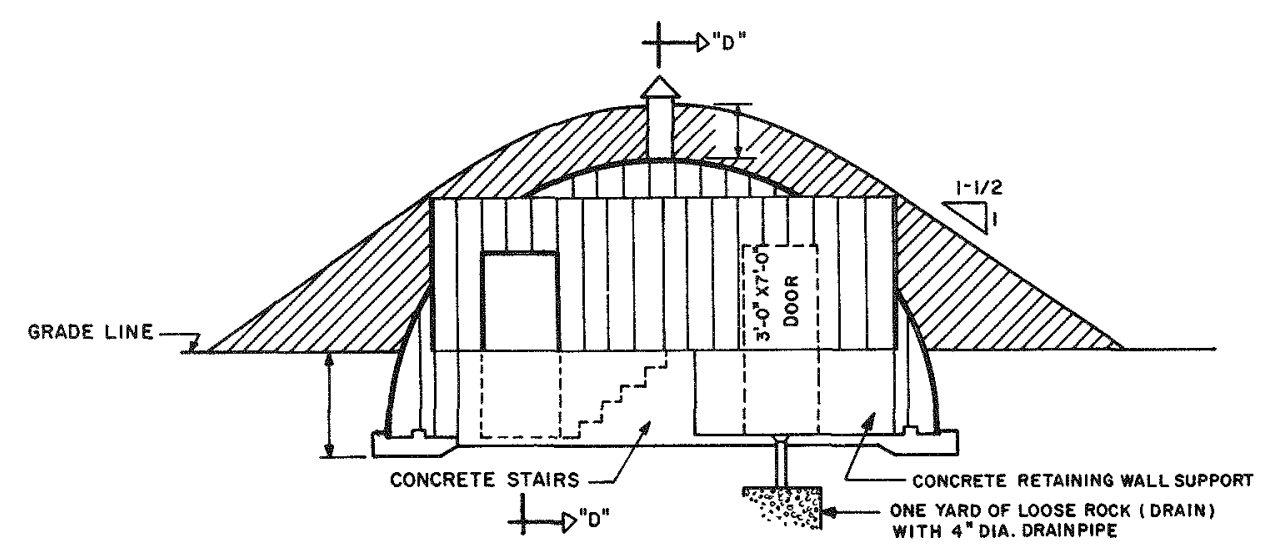

Fig. 1.2- South end (main entrance) elevation of shelter. 


\section{Chapter 2}

\section{EXPERIMENTAL METHOD}

\subsection{GENERAL DESCRIPTION}

Two distinct types of measurements had to be made to obtain the data required to evaluate the shelter. First, the exposure dose rate was measured inside the shelter from a radioactive source evenly distributed on the ground above and surrounding the shelter. Second, the pulseheight distribution of the radiation as it entered the shelter was measured using the same source geometry.

For the first measurement a 196 -curie $\mathrm{Co}^{60}$ source was pumped at a uniform rate through a length of tubing. This tubing was prepositioned over and around the shelter so that the amount of tubing per unit area was constant. The source was pumped at a uniform rate, thus simulating an area of uniformly distributed radioactivity. Radiation doses were measured inside the structure at the desired locations by highly sensitive ionization chambers.

For the pulse-height distribution measurements, a 16.3 -curie $\mathrm{Co}^{60}$ source was pumped through the tubing, which was laid out in the same configuration as for the dose measurements. A 256-channel analyzer was used to obtain the energy measurements.

\subsection{MOVING-POINT-SOURCE SYSTEM}

For this project, a method of source circulation similar to the one used during the CEX58.6, CEX-59.13, and CEX-60.1 experiments was used. This system consisted of a hydraulic pumping unit, associating tubing, source-position indicators, a remote-control console, source shield (pigs), 200 - and 20 -curie $\mathrm{Co}^{60}$ source containers (slugs), and interconnecting cables. The $\mathrm{Co}^{60}$ slug was pumped from the pig, through the tubing, and back into the pig.

Three vehicles contained the apparatus. The hydraulic system and source shields were mounted on one truck. Tubing reels, power-and signal-cable reels, and a 5-kw emergency generator were on a caisson trailer (Fig. 2.1). A laboratory truck contained the control console, tools, supplies, and general equipment for the system (Fig. 2.2).

A means of storing the slug when it was not being pumped through the tubing was provided by the 200-curie $\mathrm{Co}^{60}$ source shield. Two $\mathrm{S}$-shaped stainless-steel tubes in which the slug traveled were within the shield. Stops were provided in the center of each tube to halt the motion of the slug when it returned to the shield. A method was devised for locking the slug in place when it was not being used. A picture of this shield is presented in Fig. 2.3.

A modified shipping container comprised the 20 -curie $\mathrm{Co}^{60}$ source shield. The two source shields, an air compressor (used to empty the water from the tubing), and the hydraulic system were mounted in a truck (Fig. 2.4).

The hydraulic pumping system consisted of a 120-gal reservoir, a 1-hp 220-volt electric motor, a piston type positive-displacement pump, filters, several hand-operated and electrically operated solenoid valves, and connecting lines. The outside diameter of the source cap- 
sule was slightly less than the inside diameter of the tubing. A flow system rather than a pressure-differential system was employed. The internal pressure in normal operation was about $100 \mathrm{psi}$ when $3000 \mathrm{ft}$ of tubing was ised, and the source traveled at $120 \mathrm{ft} / \mathrm{min}$.

An emergency hand pump capable of retrieving the slug from either direction was provided as an auxiliary unit in the event of failure of the main unit. This hand device was situated $100 \mathrm{ft}$ away from the source shield (Fig. 2.5).

Operation of the system was remotely controlled from the console (Fig. 2.6) in the laboratory truck, about $500 \mathrm{ft}$ from the pumping system. It was possible to start, stop, or reverse the movement of the slug with maximum speed obtainable in either direction from this console. Twenty movable magnetic indicators (Fig. 2.7) were used to locate the slug as it moved through the tubing. These indicators were clamped to desired points on the tubing and were connected individually to a series of lights on the console panel.

The $\mathrm{Co}^{60}$ source was encapsulated in a magnetic stainless-steel container. It was conveyed by water through $1 / 2$-in. Marlex (high-density polyethylene) tubing, rated at 200-psi hoop-stress at $130^{\circ}$ for a one-year period. Burst pressure was rated in excess of $1000 \mathrm{psi}$. The tubing bend radius was limited to a minimum of $2 \mathrm{ft}$.

\subsection{SOURCES}

Radioactive sources used during this experiment were:

1. One 196-curie $\mathrm{Co}^{60}$ source

2. One 16.3-curie $\mathrm{Co}^{60}$ source

3. One $2.86-\mathrm{mc} \mathrm{Co}^{60}$ source

The 196 -curie $\mathrm{Co}^{60}$ source was doubly encapsulated in magnetic stainless-steel containers. Two containers (each holding approximately 100 curies) were connected by a flexible -steel cable $3 / 4$ in. long (Fig. 2.8). The outside diameter of the container was slightly less than the inside diameter of the tubing, thus allowing the source to pass through the tubing (even when curved) with ease and safety. The source had been calibrated during a previous exercise and indicated at the time of this experiment a strength of 196 curies.

The 16.3-curie $\mathrm{Co}^{60}$ source was also encapsulated in a magnetic stainless-steel container. This source also had been calibrated during a previous exercise; at the time of this experiment a strength of 16.3 -curies was indicated.

The $2.86-\mathrm{mc} \mathrm{Co}^{60}$ source was normally used for demonstration purposes. It was calibrated by ionization chambers.

\subsection{INSTRUMENTATION}

The instrumentation used in this experiment included pocket ionization chambers, associated charger readers, and a 256 -channel analyzer.

Pocket ionization chambers were:

1. 10 Bendix model 6110 - to $5-\mathrm{r}$ chambers

2. 75 Victoreen model 3620 - to $200-\mathrm{mr}$ chambers

3. 145 Victoreen model 2390 - to $10-\mathrm{mr}$ chambers

Victoreen model 287 minometers were used for charging and reading the model 362 and 239 ionization chambers (see Fig. 2.9).

Ionization chambers were calibrated prior to the experiment with a $\mathrm{Co}^{60}$ standard. Figure 2.10 is a sample calibration curve.

An energy-response curve was obtained from the Victoreen Instrument Company for the 0 - to 10-mr chambers (Fig. 2.11).

The 256-channel analyzer and associated equipment (Fig. 2.12) were used to measure the energy of the radiation entering the shelter. The system consisted of:

1. A 2 -in. by 2 -in. NaI crystal optically coupled to a photomultiplier tube

2. A Nuclear Data model ND-101 transistorized 256 -channel analyzer

3. A John Fluke model $402 \mathrm{M}$ high-voltage supply

4. An IBM typewriter for automatic numerical print-out 


\subsection{EXPERIMENTAL TECHNIQUE}

The experimental technique consisted in measuring the radiation at points within the shelter from a simulated contaminated area of known source strength above and surrounding the shelter. This contaminated field was simulated by moving a point source at constant speed over the area of interest so that the source spent the same time interval per unit area over the entire area. By the use of dose-integrating detectors within the shelter, the total radiation dosage was made to appear as if arising from an area source. This technique has the advantage of averaging local features of the terrain and the building under test in much the same way as would a true fallout field.

Approximately $3000 \mathrm{ft}$ of tubing was used, covering approximately 12,000 sq ft (Figs. 2.13 through 2.15).

The radiation-dose measurements were obtained by pumping a 196 -curie $\mathrm{Co}^{60}$ source through the tubing and measuring the accumulated doses with the low-range ionization chambers (10 $\mathrm{mr}$ full scale). The actual test exposure was approximately $2 \frac{1}{2} \mathrm{hr}$ to ensure readings sufficiently high for valid statistical evaluation.

Experiment procedures consisted of the following:

1. The polyethylene tubing was distributed over the desired area according to a predetermined plan.

2. A dummy source capsule was then pumped through the tubing to make certain it had not been damaged during placement. At this time, the dosimeters were charged.

3. The dosimeters were placed in paper cups attached to strings hung from aluminum stands (Fig. 2.16).

4. When radiological safety clearance was given, the system was energized, and the test run was made. At the conclusion of the test exposure, the source was secured in its shield, the dosimeters were read, and the readings were recorded.

The accumulation of fallout on top of the air vents was simulated by placing a point source of $2.86 \mathrm{mc}$ in the center (on top) of one of the vents (see Fig. 2.17). Dosimeters were placed 21 in. off center as well as directly below the air vent.

Measurements of the radiation energy entering the shelter were made using the same tubing configuration used for the dose measurements. These energy measurements were made employing a 16.3-curie $\mathrm{Co}^{60}$ source as well as the 196-curie $\mathrm{Co}^{60}$ source. Data were taken at three positions at a height of $4 \mathrm{ft}$ above the floor inside the shelter. These positions (Fig. 2.18) were: (1) near the center between two vents (position $A$ ), (2) near a corner at the front entrance (position B), and (3) exact center under a vent (position $C$ ).

In addition, measurements were made $3 \mathrm{ft}$ above the center of a square simulated area source 54 by $54 \mathrm{ft}$. The tubing was placed on the ground (in a level unobstructed area) with a $4 \frac{1}{2}$-ft spacing, and the $2.86-\mathrm{mc} \mathrm{Co}^{60}$ source was pumped through it. These measurements were taken to ascertain the energy spectrum $3 \mathrm{ft}$ above a plane source of radiation. Backgrounds were taken for all measurements.

Unauthorized entrance into the test area was restricted during the test runs. A radiological safety plan was formulated, and this plan served as a basis for conducting the experiment (Appendix A).

The test was performed at night to minimize inconvenience to workers in nearby buildings. Telephone contact was maintained at all times with the local representatives during the test exposures. 


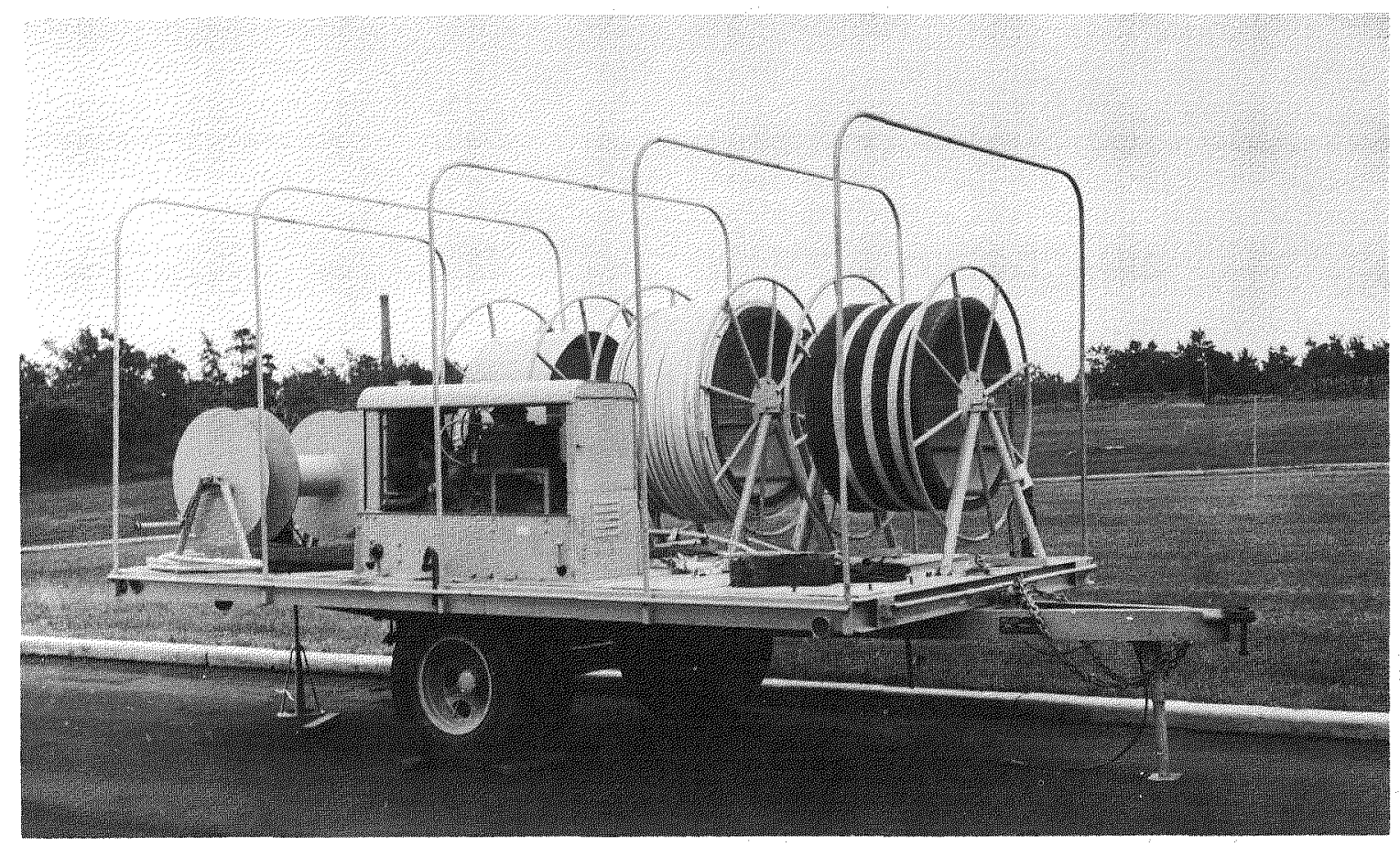

Fig. 2.1-Caisson trailer.

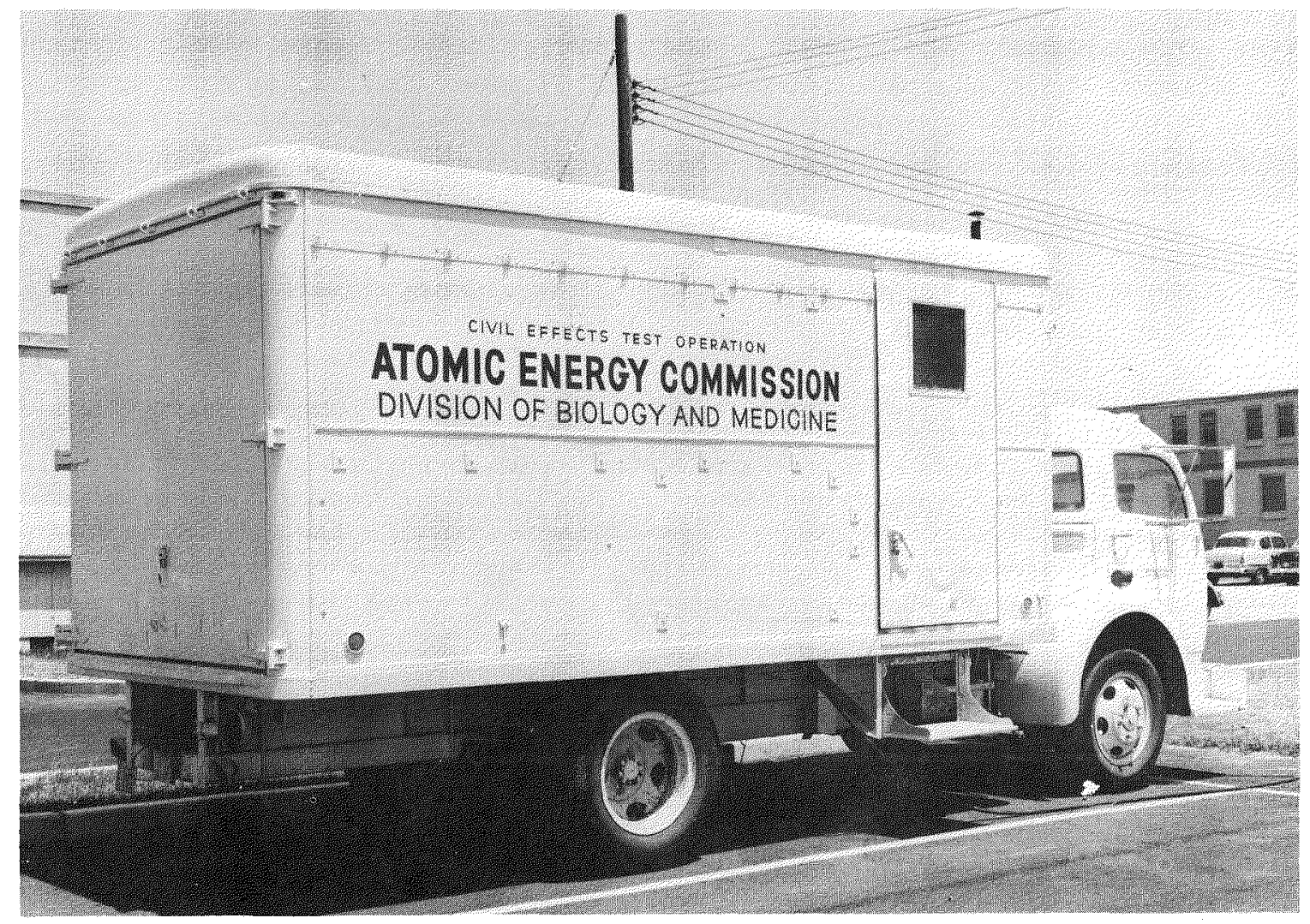

Fig. 2.2-Laboratory truck. 


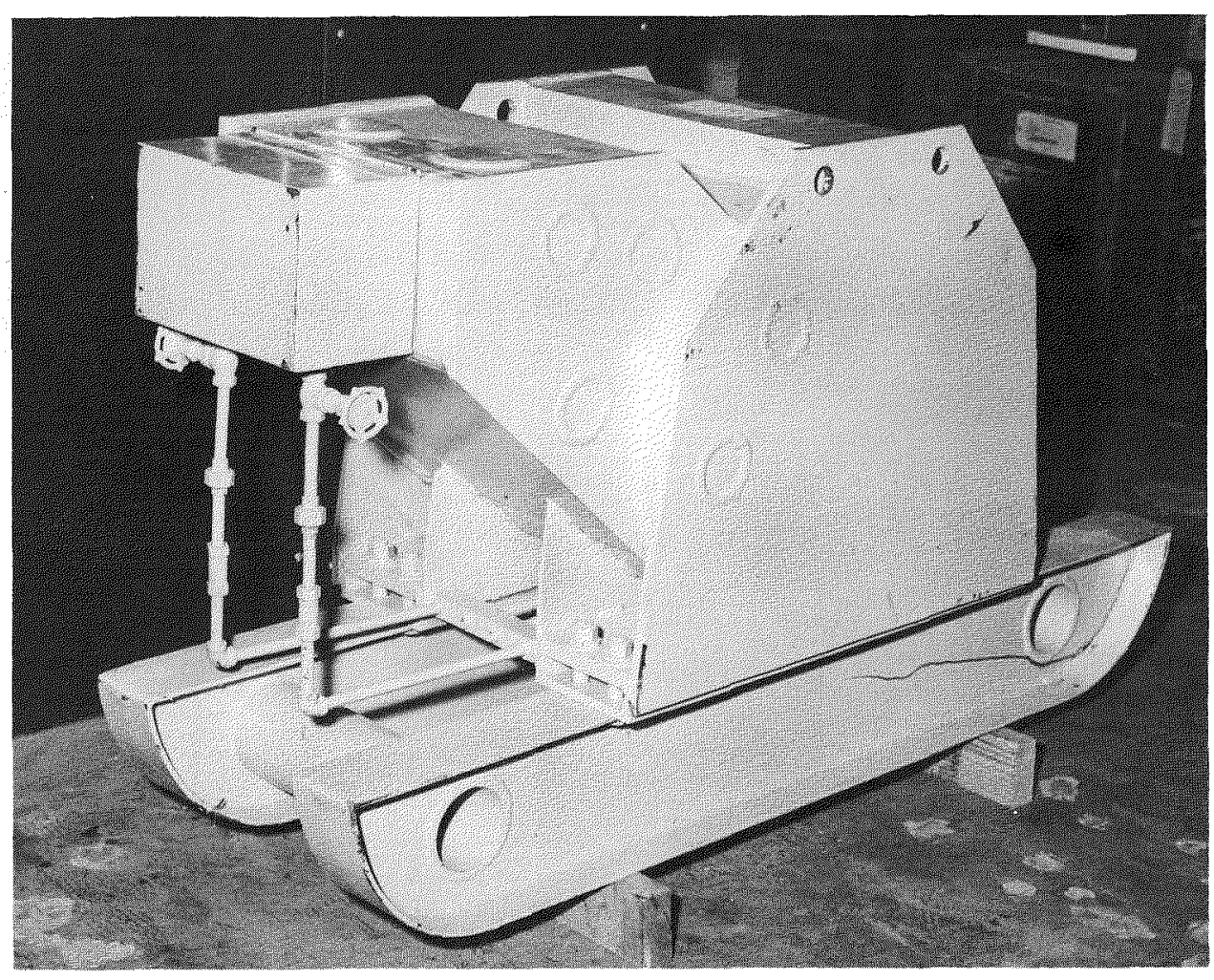

Fig. 2.3-The 200-curie $\mathrm{Co}^{60}$ source shield.

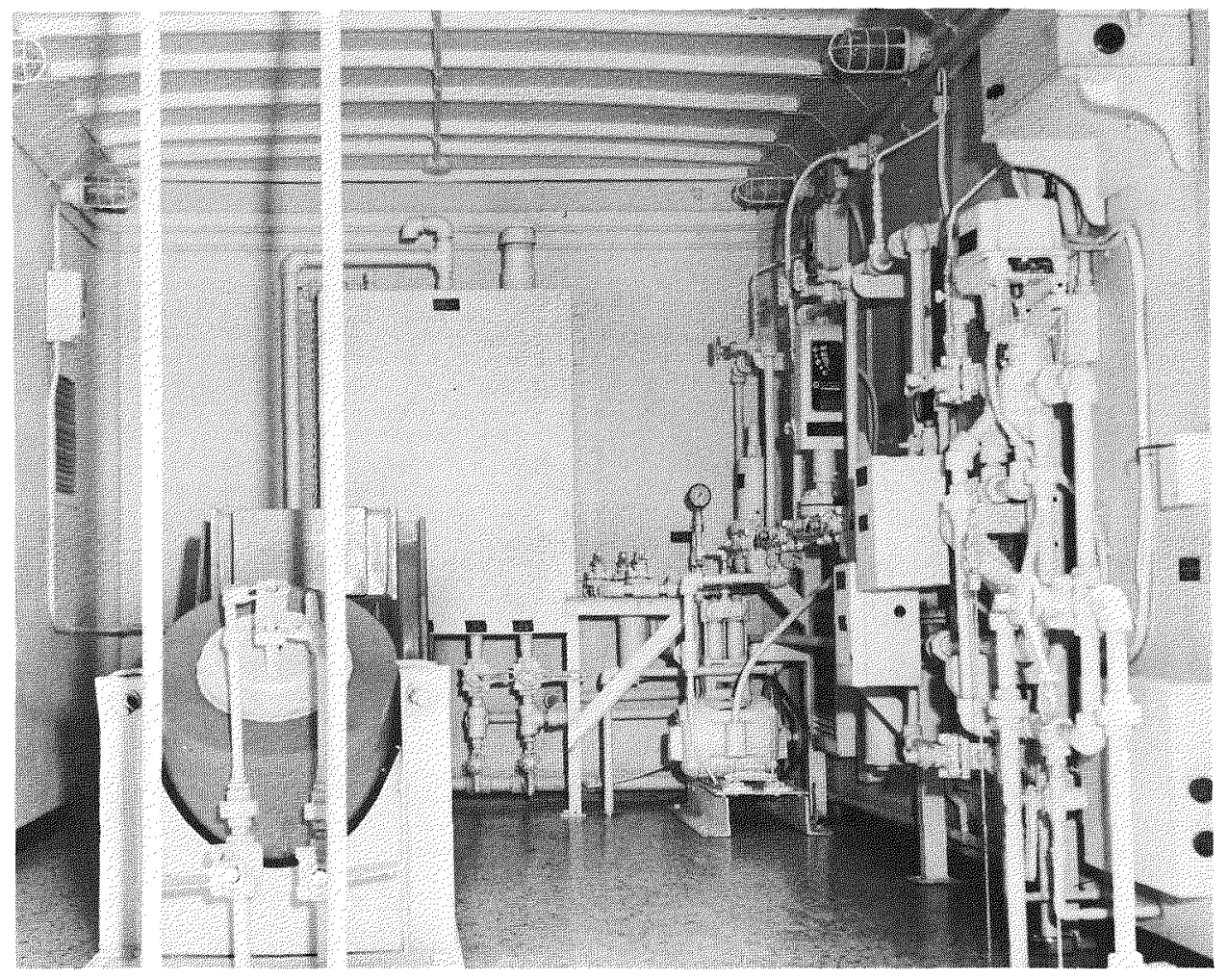

Fig. 2.4-Interior of source truck showing shields and pumping system. 


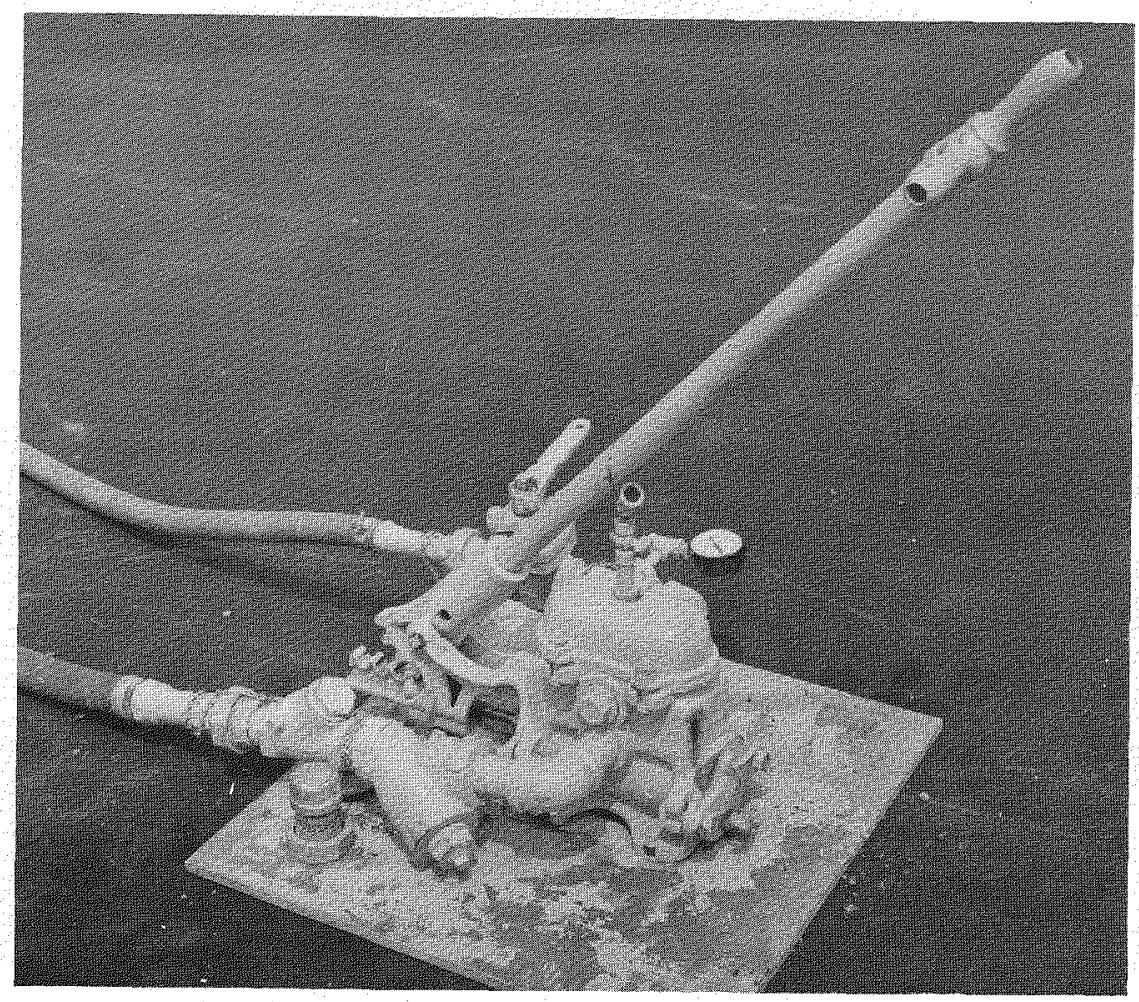

Fig. 2.5-Emergency hand pump.

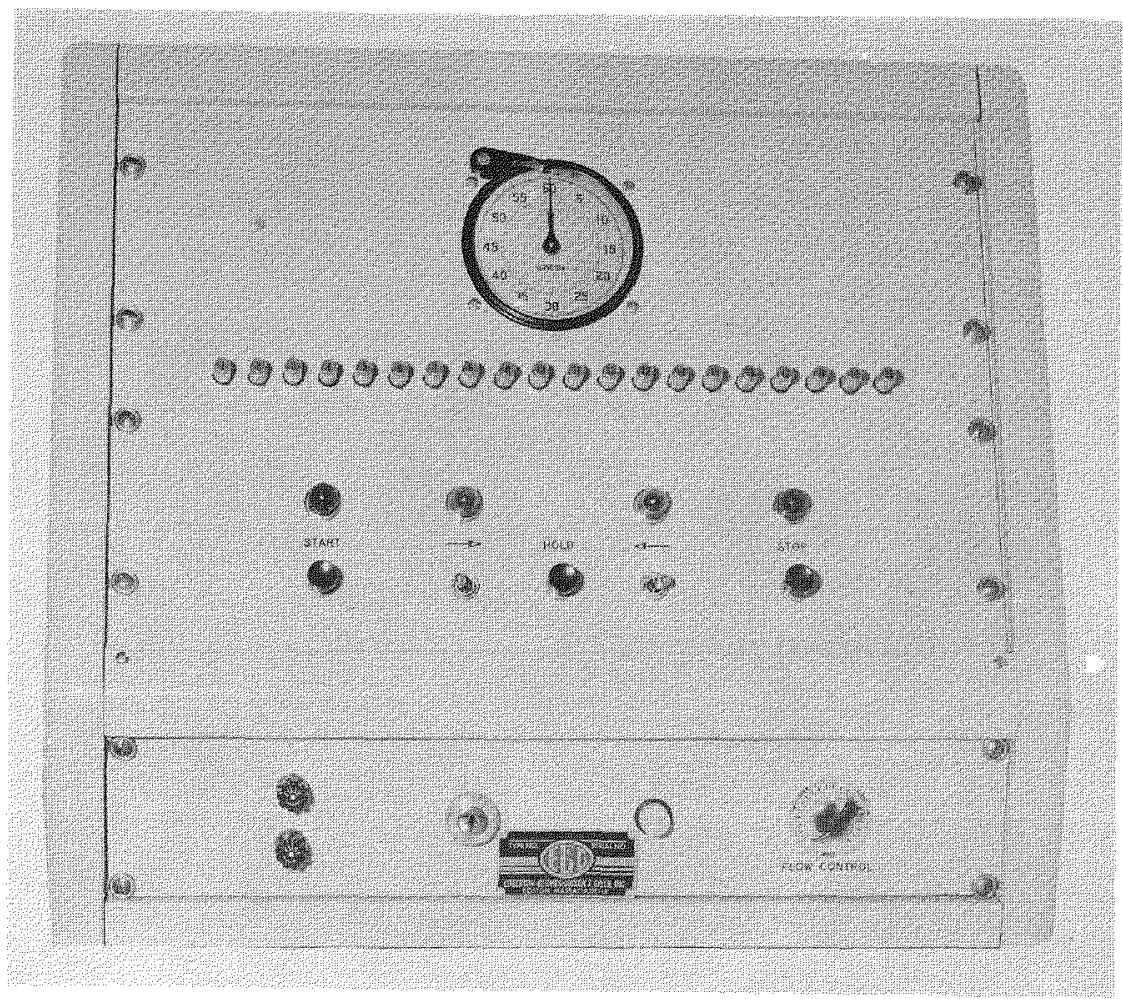

Fig. 2.6-Remote-control console. 


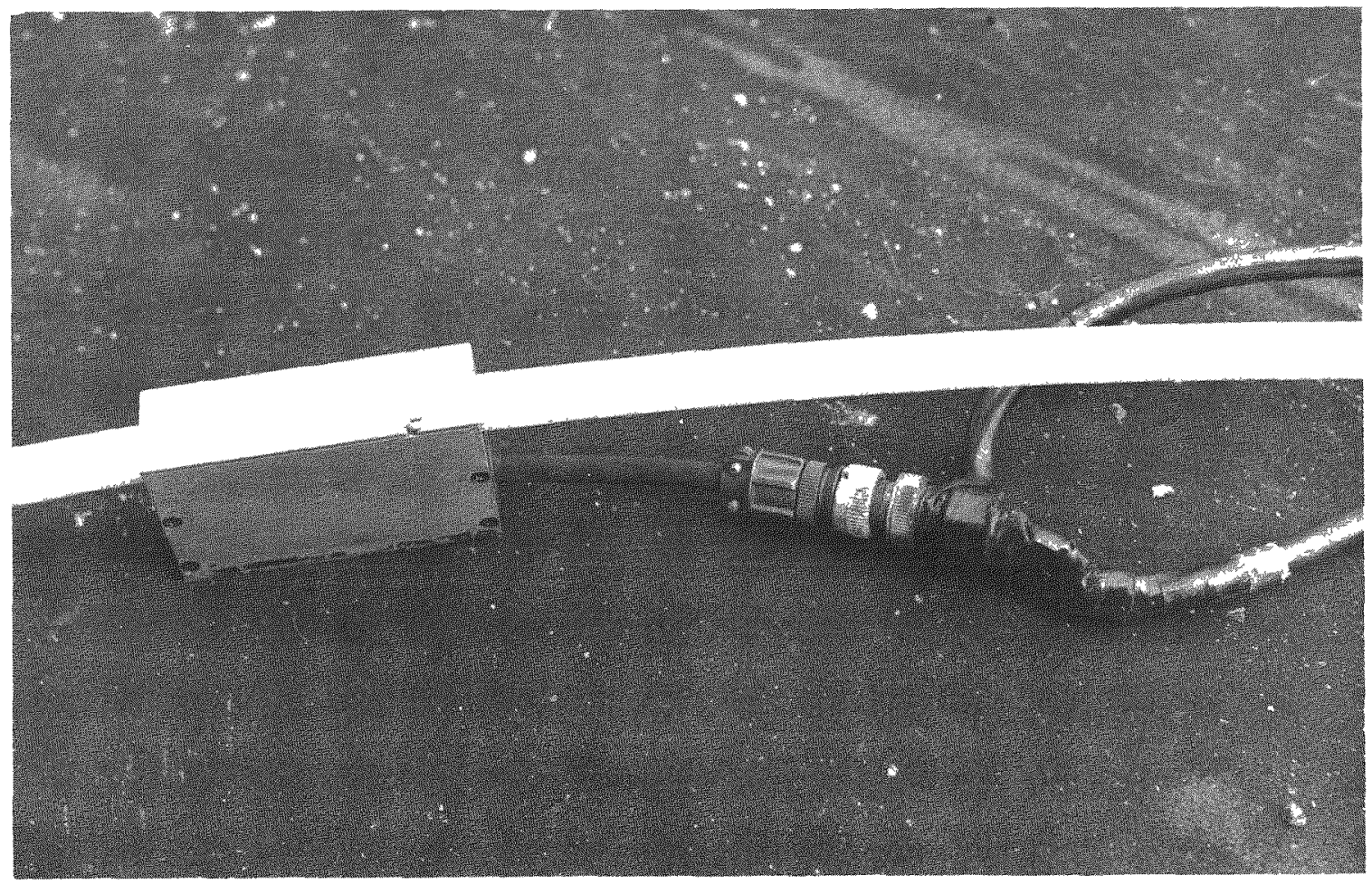

Fig. 2.7-Source-position indicator.
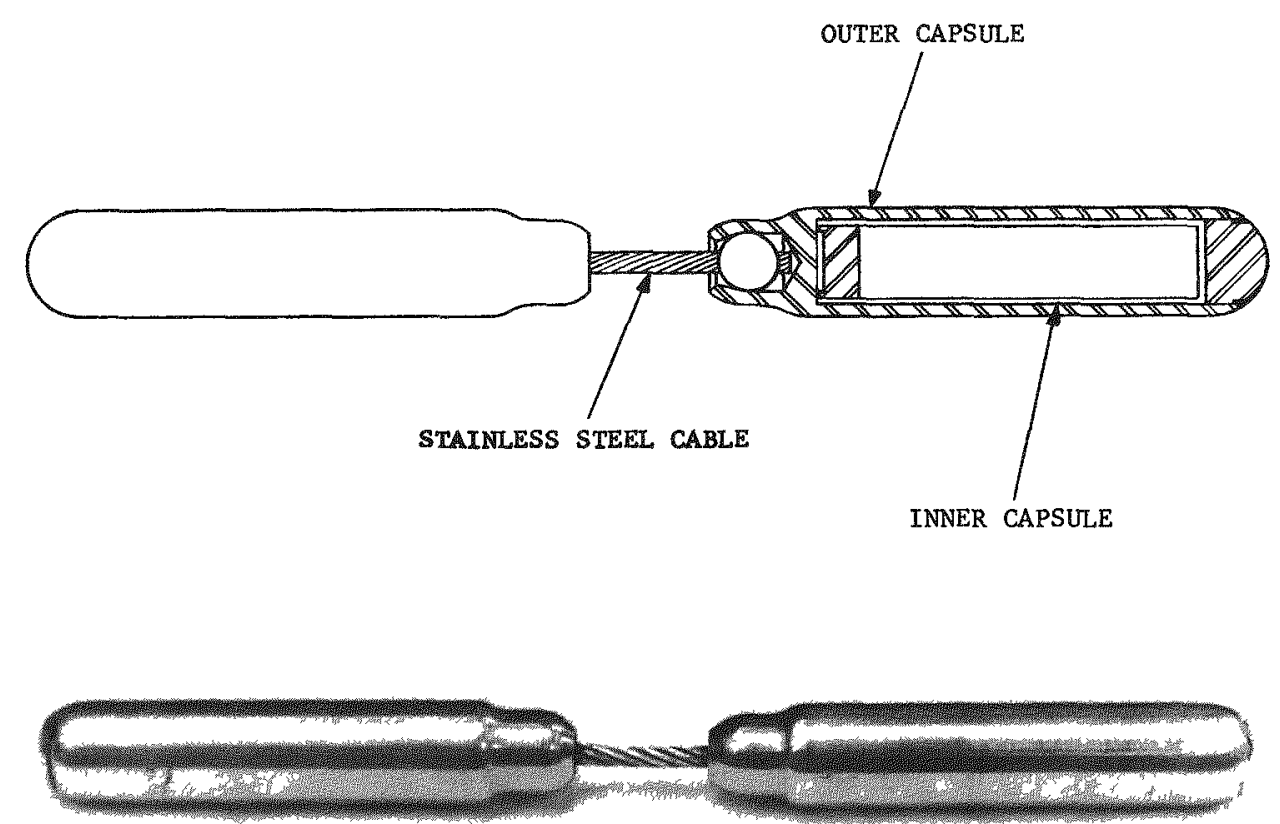

F1g. 2.8-The 200-curie $\mathrm{Co}^{60}$ source capsule. 


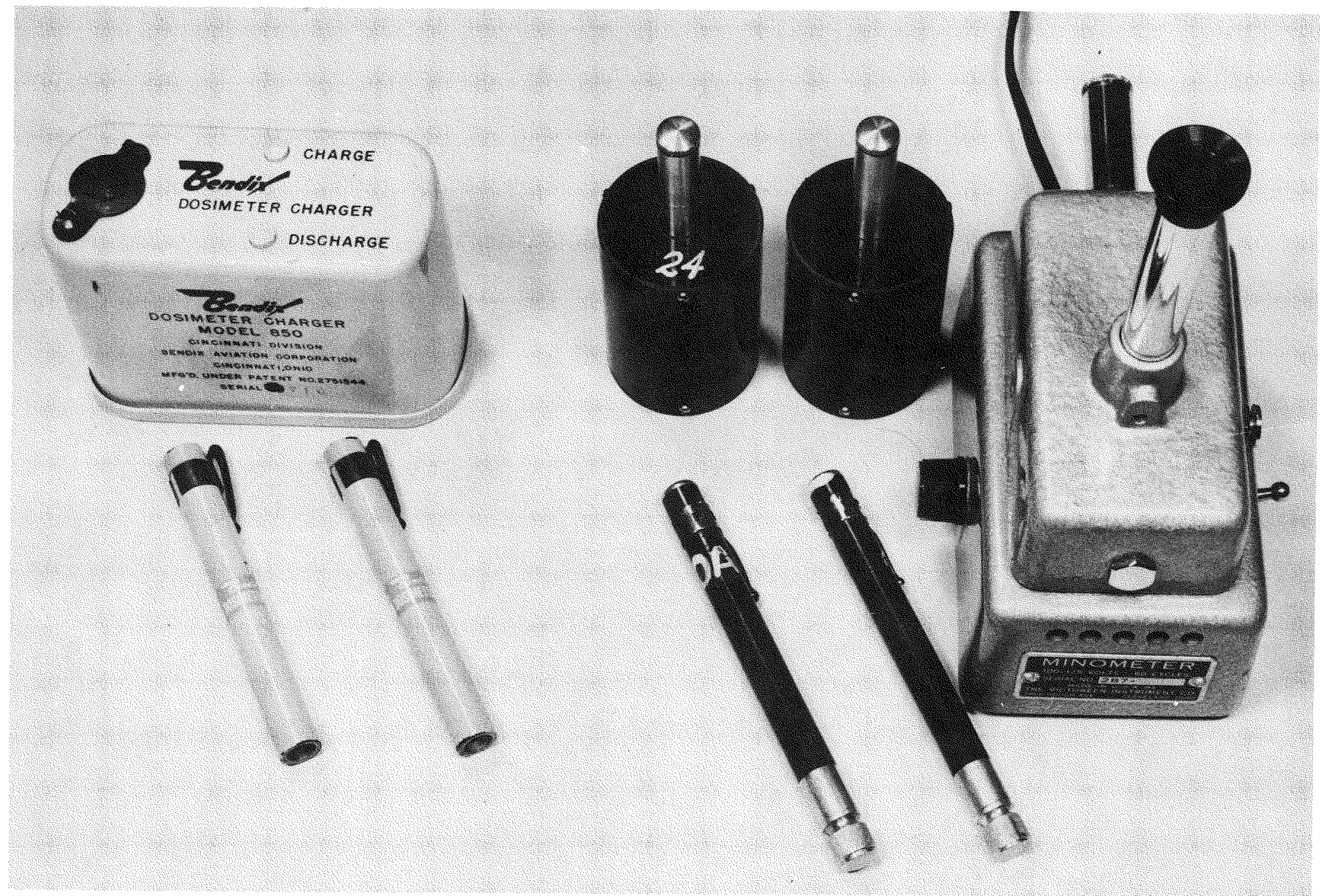

Fig, 2.9-Ionization chambers and charger-readers. 




Fig. 2.10-Calibration curve for Victoreen model 239 ıonization chambers. 


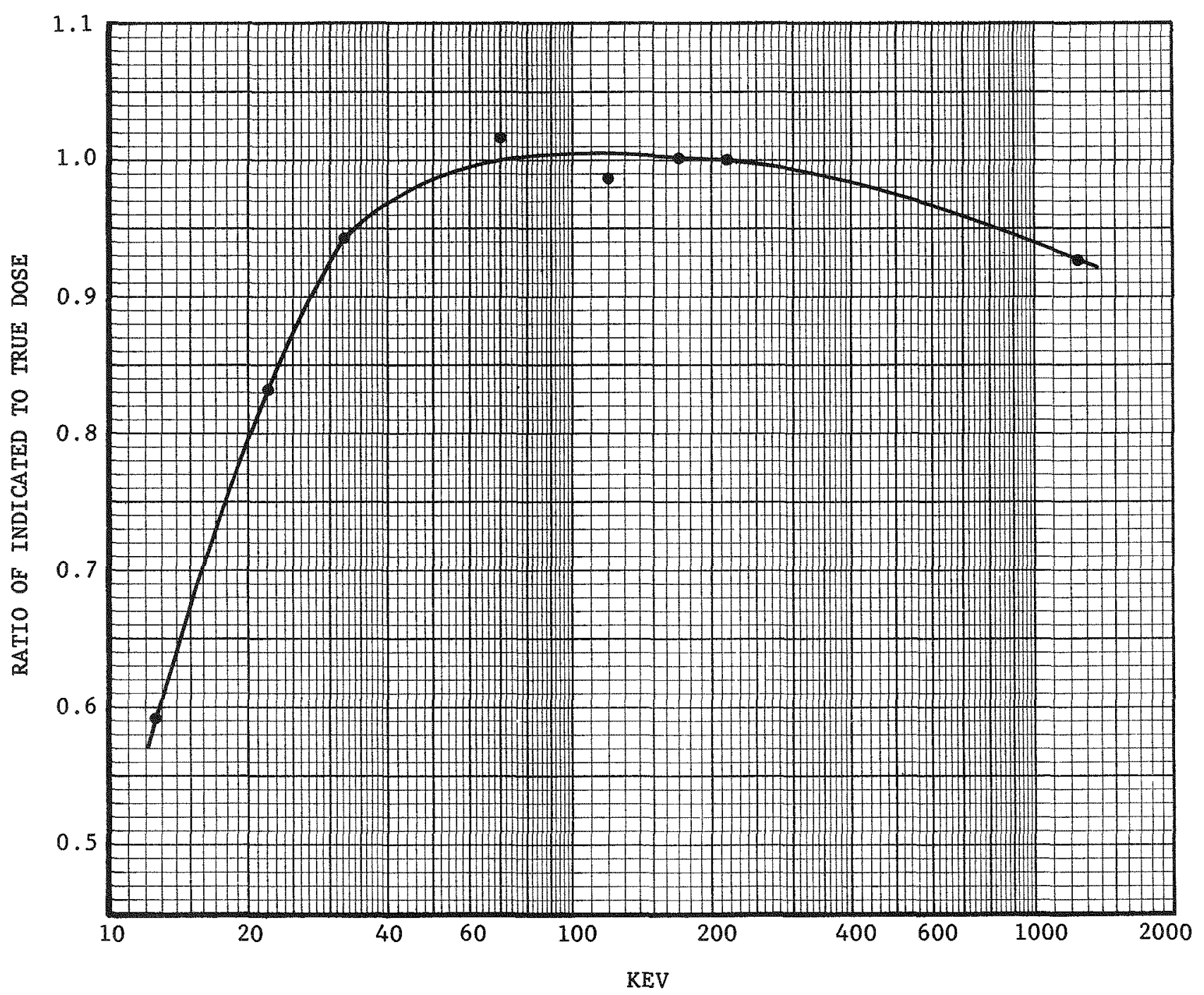

Fig. 2.11-Energy response of Victoreen model 239 ionization chamber. 



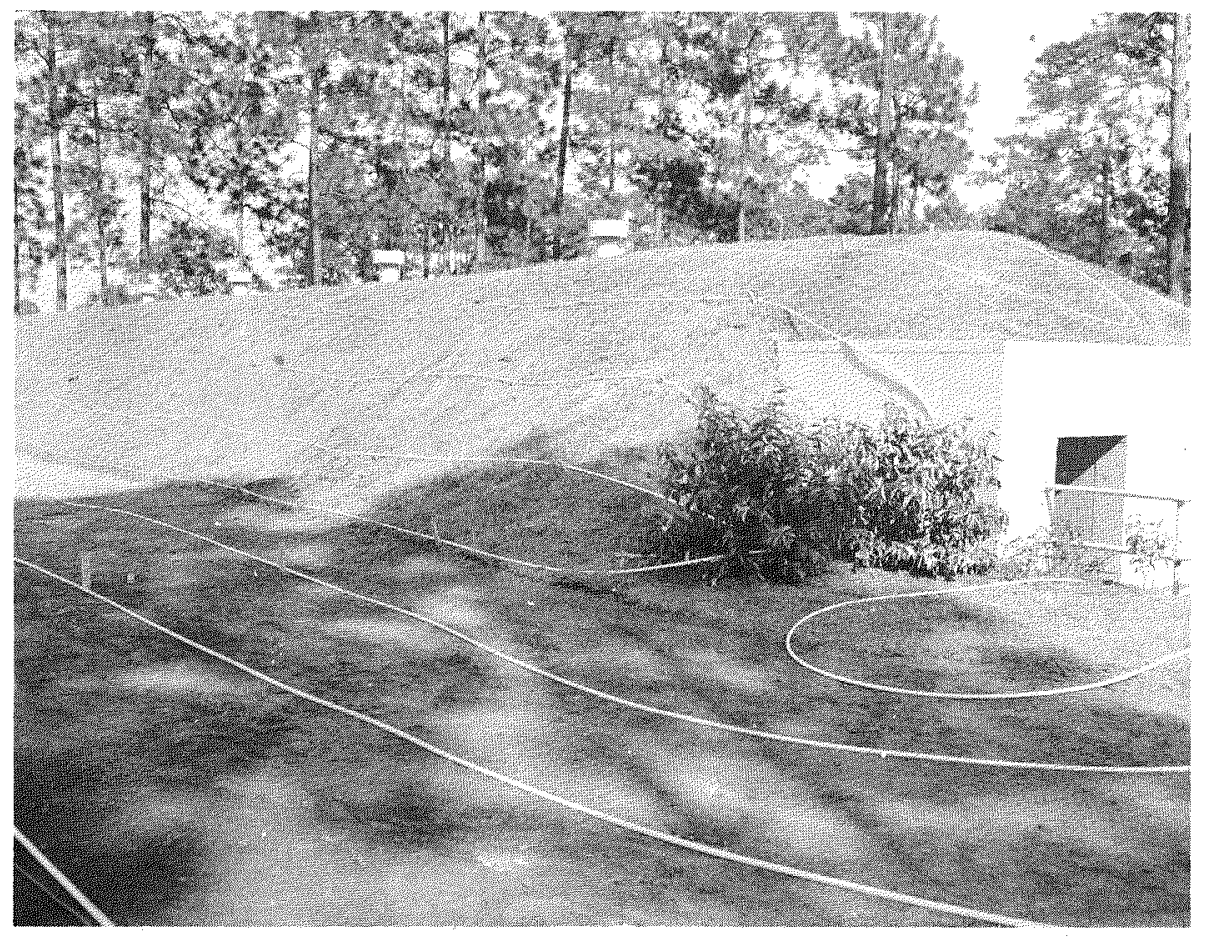

Fig. 2.13-Tubing layout at shelter. 


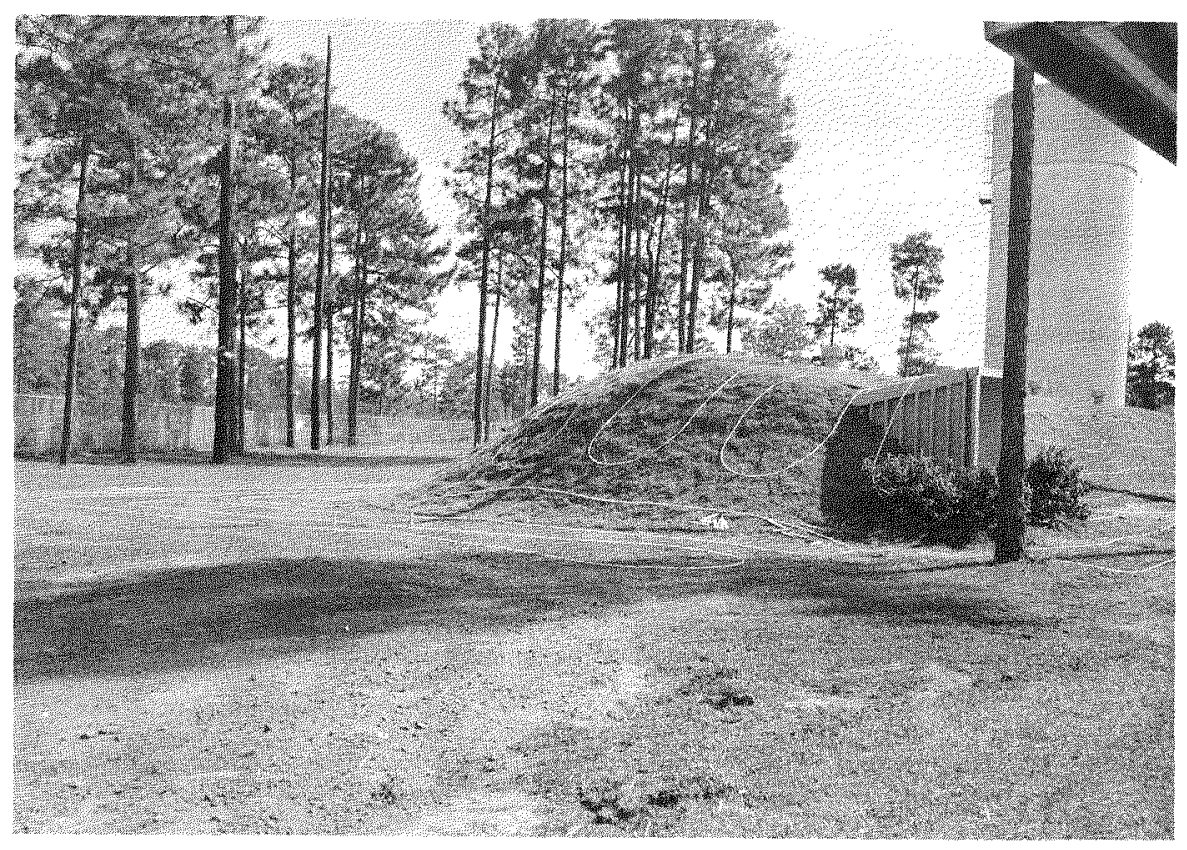

Fig. 2.14-Tubing layout at shelter.

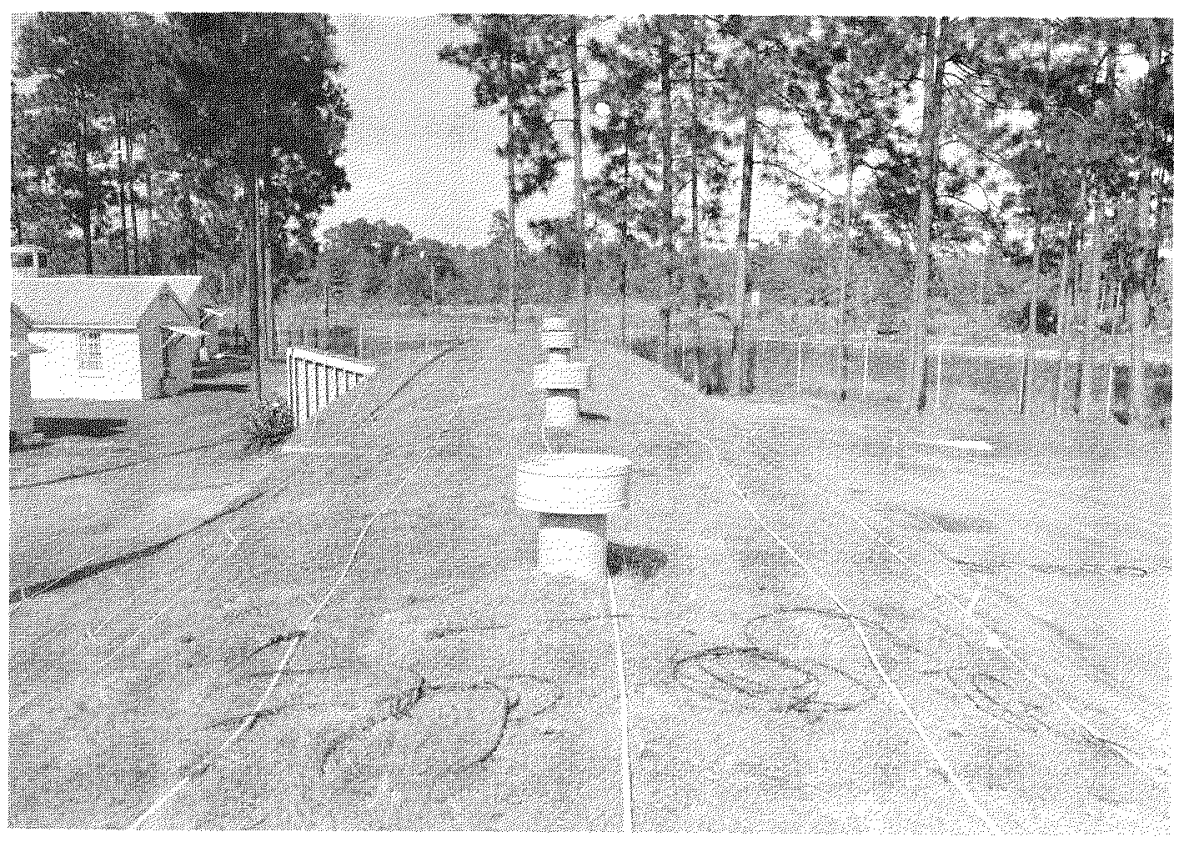

Fig. 2.15- Tubing layout at shelter. 


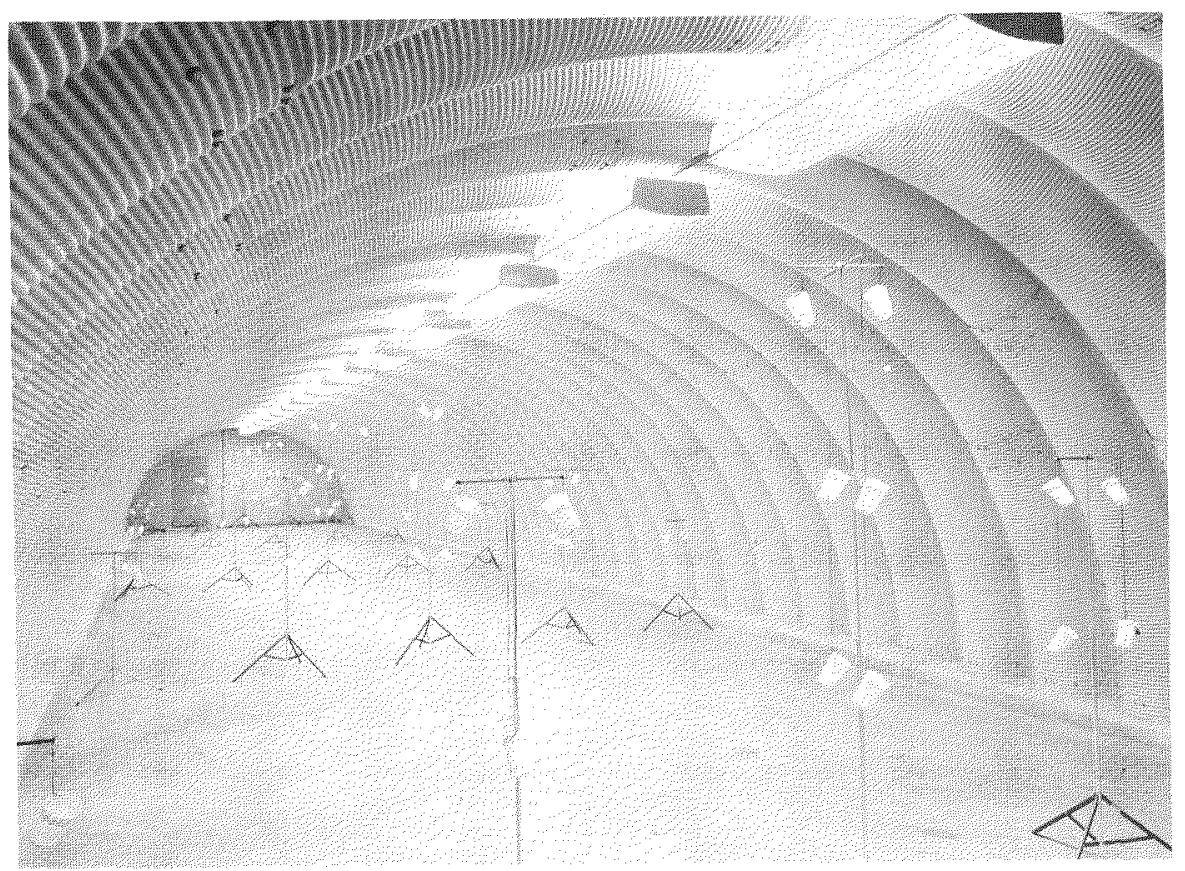

Fig. 2.16- Dosimeter positions inside shelter.

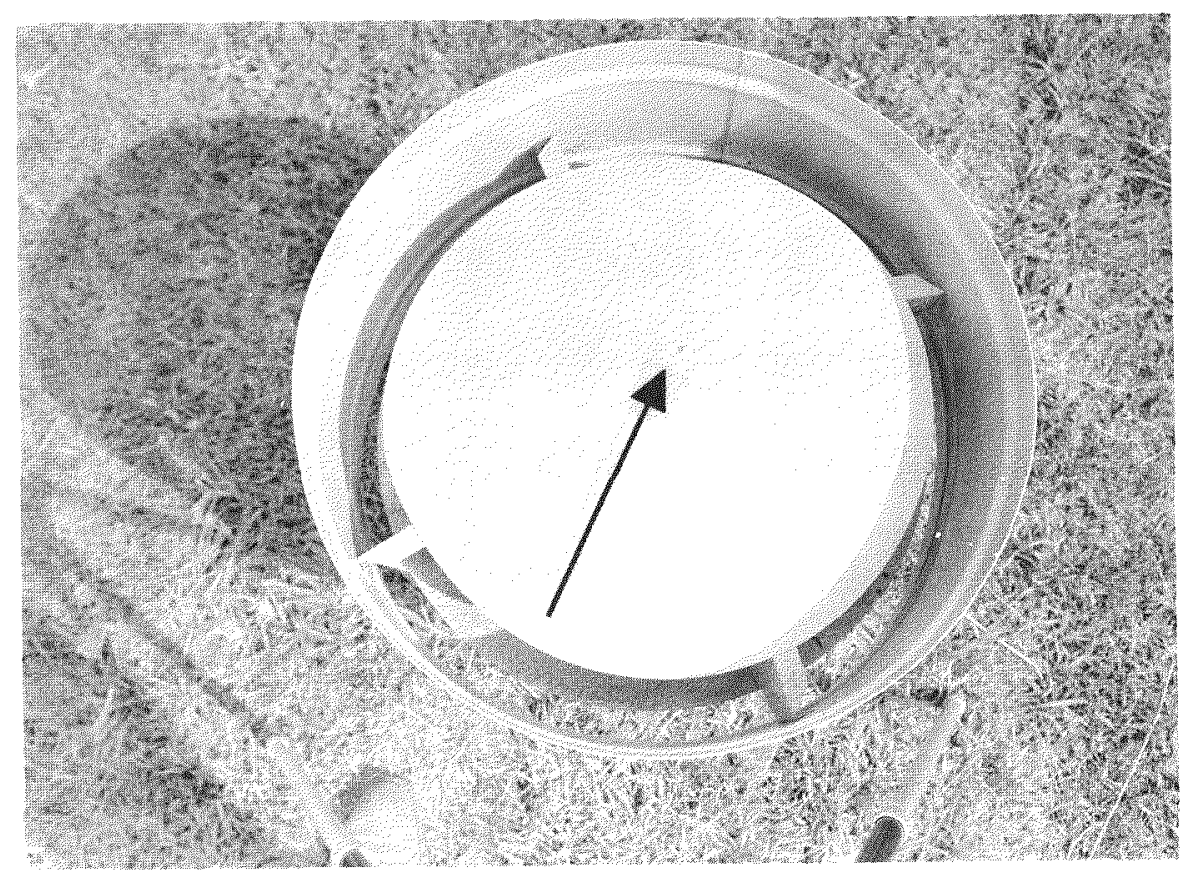

Fig. 2.17-Air vent on top of shelter. Arrow shows position of point source. 


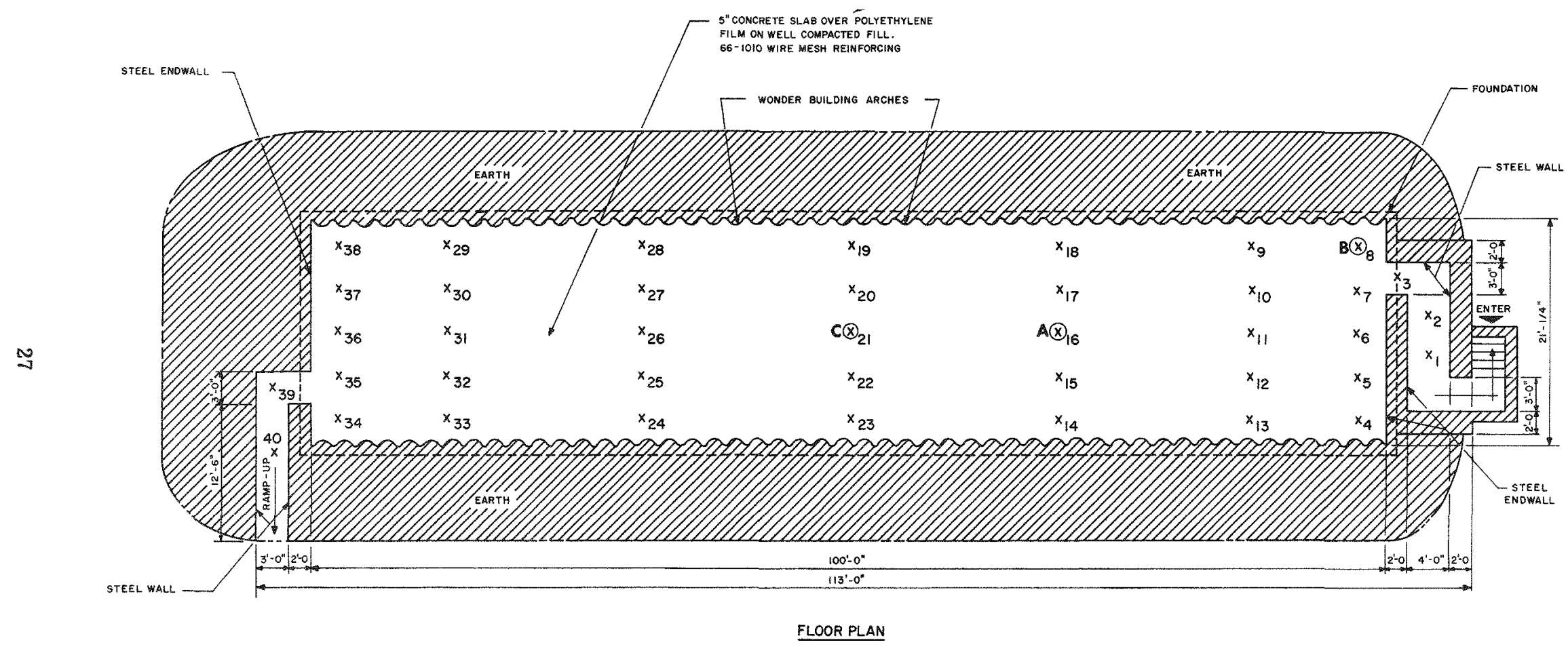

Fig. 2.18-Floor plan of shelter showing crystal assembly $(A, B, C)$ and dosimeter $(X)$ positions. 


\section{Chapter 3}

\section{PRESENTATION OF DATA}

\subsection{DOSE MEASUREMENTS}

An area source of radioactivity was simulated over and around the shelter, and dose measurements were made within. The 196 -curie $\mathrm{Co}^{60}$ source was pumped through the tubing, which was evenly distributed over an area of $11,160 \mathrm{sq} \mathrm{ft}$. The exposure time was $2.456 \mathrm{hr}$.

At least two dosimeters were placed at each position. Their readings were averaged and corrected for leakage, temperature, pressure, and calibration and then normalized to milliroentgens per hour per millicurie per square foot. Figure 2.18 shows a floor plan of the shelter with dosimeter position numbers. The normalized data are presented in Table 3.1 at different heights above the floor and at various positions throughout the shelter.

\subsection{ENERGY MEASUREMENTS}

Presented in Fig. 3.1 is a pulse-height distribution taken by placing a $\mathrm{Co}^{60}$ standard directly on the face of the 2 - by 2-in. crystal. The energy peaks at 1.17 and $1.33 \mathrm{Mev}$ are quite evident. Measurements of the pulse-height distribution were taken $3 \mathrm{ft}$ above a rectangular simulated area source using $\mathrm{Co}^{60}$. These measurements appear in Fig. 3.2. The pulse-height distribution of the radiation entering the shelter appears in Figs. 3.3 through 3.6. Two measurements were taken using the 196-curie source, and two were taken using the 16.3-curie source. (Detector-assembly positions appear in Fig. 2.18.)

\subsection{POINT-SOURCE MEASUREMENTS}

$\mathrm{A} \mathrm{Co}^{60}$ point source of $2.86 \mathrm{mc}$ was placed on the top of one of the vents, and dose measurements were taken directly below. The area of the top of the vent was $1.766 \mathrm{sq} \mathrm{ft}$, and the exposure time was $3.00 \mathrm{hr}$. The normalized data appear in Table 3.2 . 
Table $3.1-$ DOSE RATES INSIDE THE SHELTER

\begin{tabular}{|c|c|c|c|c|c|c|c|c|c|}
\hline \multirow[b]{2}{*}{ Position } & \multicolumn{4}{|c|}{ Dose rate* } & \multirow[b]{2}{*}{ Position } & \multicolumn{4}{|c|}{ Dose rate* } \\
\hline & At $1 \mathrm{ft}$ & At $3 \mathrm{ft}$ & At $5 \mathrm{ft}$ & At $7 \mathrm{ft}$ & & At $1 \mathrm{ft}$ & At $3 \mathrm{ft}$ & At $5 \mathrm{ft}$ & At $7 \mathrm{ft}$ \\
\hline 1 & & 2.1 & & & 21 & & 0.10 & 0.11 & 0.12 \\
\hline 2 & & 0.60 & & & 22 & & 0.70 & 0.072 & \\
\hline 3 & & 0.35 & & & 23 & 0.037 & 0.033 & & \\
\hline 4 & 0.091 & 0.15 & & & 24 & & 0.037 & & \\
\hline 5 & & 0.21 & 0.32 & & 25 & & 0.072 & 0.081 & \\
\hline 6 & & 0.19 & 0.27 & 0.28 & 26 & & 0.095 & 0.10 & 0.10 \\
\hline 7 & & 0.20 & 0.29 & & 27 & & 0.081 & 0.084 & \\
\hline 8 & 0.070 & 0.085 & & & 28 & & 0.030 & & \\
\hline 9 & & 0.058 & & & 29 & & 0.033 & & \\
\hline 10 & & 0.12 & 0.17 & & 30 & & 0.098 & 0.10 & \\
\hline 11 & & 0.14 & 0.16 & 0.15 & 31 & & 0.12 & 0.12 & 0.11 \\
\hline 12 & & 0.11 & 0.11 & & 32 & & 0.079 & 0.070 & \\
\hline 13 & & 0.056 & & & 33 & & 0.042 & & \\
\hline 14 & & 0.044 & & & 34 & 0.044 & 0.042 & & \\
\hline 15 & & 0.091 & 0.091 & & 35 & & 0.093 & 0.097 & \\
\hline 16 & & 0.11 & 0.12 & 0.12 & 36 & & 0.18 & 0.23 & 0.26 \\
\hline 17 & & 0.086 & 0.087 & & 37 & & 0.21 & 0.31 & \\
\hline 18 & & 0.040 & & & 38 & 0.058 & 0.084 & & \\
\hline 19 & 0.037 & 0.037 & & & 39 & & 1.21 & & \\
\hline \multirow[t]{9}{*}{20} & & 0.081 & 0.081 & & 40 & & 17.4 & & \\
\hline & & Positi & \multicolumn{3}{|c|}{ Placement } & \multicolumn{2}{|c|}{ Dose rate* } & & \\
\hline & & 41 & \multicolumn{3}{|c|}{$\begin{array}{l}3 \text { in. below roof under } \\
\text { maximum thickness } \\
\text { of earth }\end{array}$} & \multicolumn{2}{|c|}{0.081} & & \\
\hline & & 42 & \multicolumn{3}{|c|}{$\begin{array}{l}3 \text { in. below roof under } \\
\text { minimum thickness } \\
\text { of earth }\end{array}$} & \multicolumn{2}{|c|}{0.14} & & \\
\hline & & 43 & \multicolumn{3}{|c|}{3 in. directly below vent } & \multicolumn{2}{|c|}{2.4} & & \\
\hline & & 44 & \multicolumn{3}{|c|}{2 ft directly below vent } & \multicolumn{2}{|c|}{0.56} & & \\
\hline & & 45 & \multicolumn{3}{|c|}{ Corner, 2 in. from wall } & \multicolumn{2}{|c|}{0.023} & & \\
\hline & & 46 & \multicolumn{3}{|c|}{ Edge, 6 in. from wall } & \multicolumn{2}{|c|}{0.12} & & \\
\hline & & 47 & \multicolumn{3}{|c|}{ Center on floor } & \multicolumn{2}{|c|}{0.086} & & \\
\hline
\end{tabular}

* Normalized to milliroentgens per hour per millicurie per square foot.

Table 3.2-DATA FROM POINT SOURCE PLACED ON VENT

\begin{tabular}{cccc}
\hline & \multicolumn{3}{c}{ Dose rate* } \\
\cline { 2 - 4 } Position & At $3 \mathrm{ft}$ & At $5 \mathrm{ft}$ & At $7 \mathrm{ft}$ \\
\hline $\begin{array}{c}\text { Directly below } \\
\text { center of vent } \\
21 \text { in. from center } \\
\text { of vent }\end{array}$ & 0.11 & 0.15 & 0.34 \\
\hline
\end{tabular}

* Normalized to milliroentgens per hour per millicurie per square foot. 


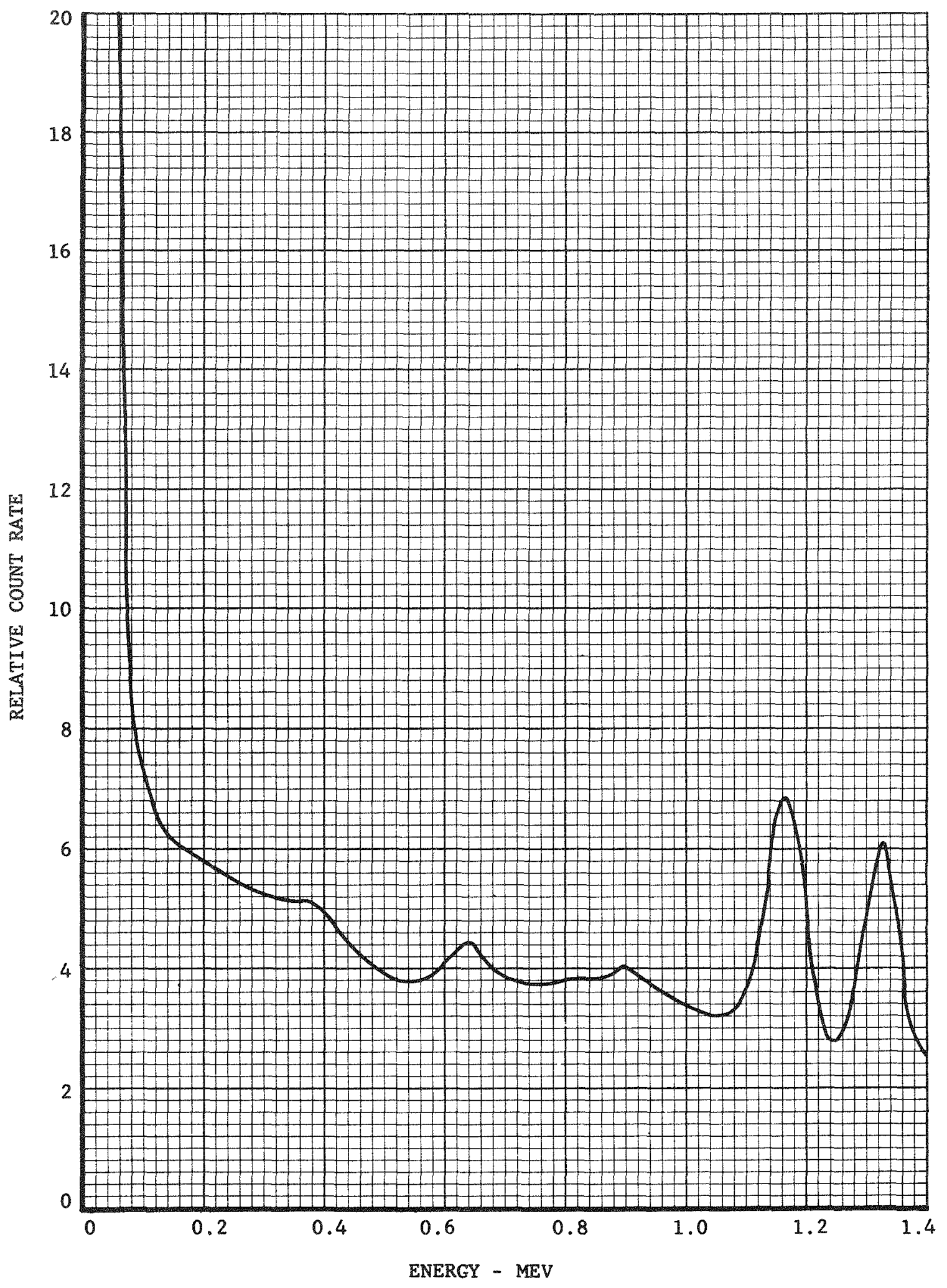

Fig. 3.1-Pulse-height distribution from $\mathrm{Co}^{60}$ standard. 


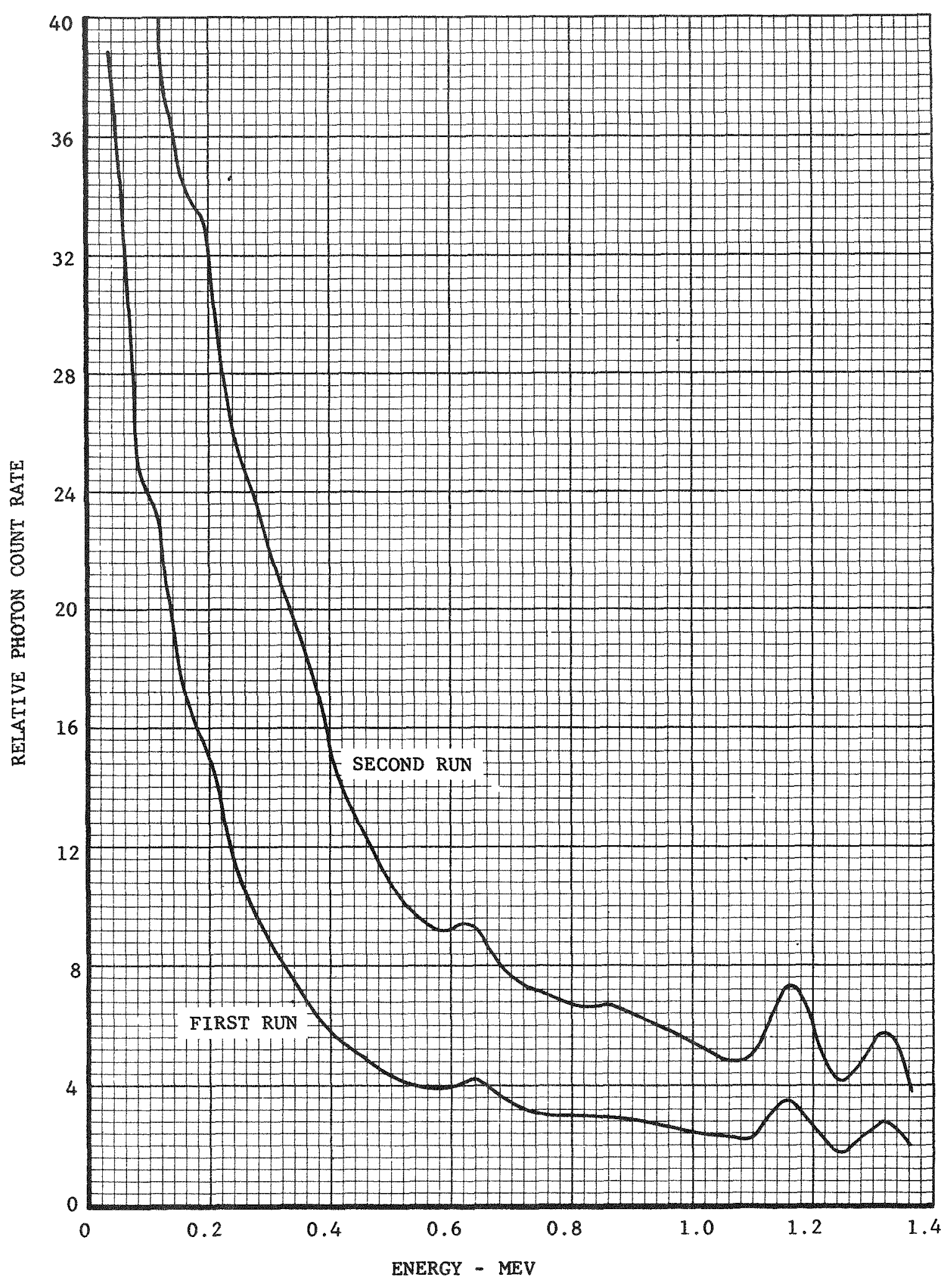

Fig. 3.2-Pulse-height distribution $3 \mathrm{ft}$ above rectangular area source. 


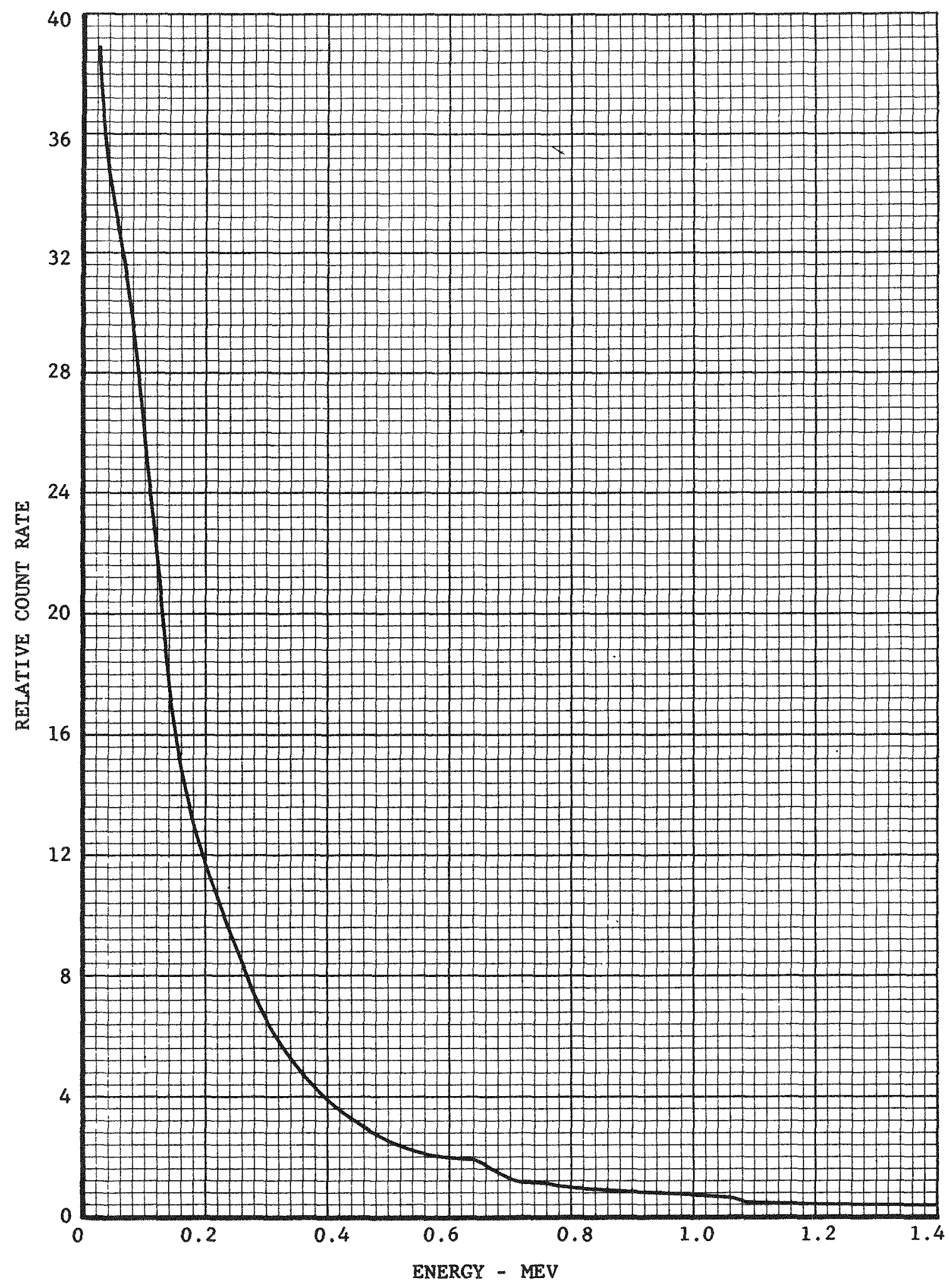

Fig. 3.3-Pulse-height distribution at position A from 196-curie $\mathrm{Co}^{60}$ source. 


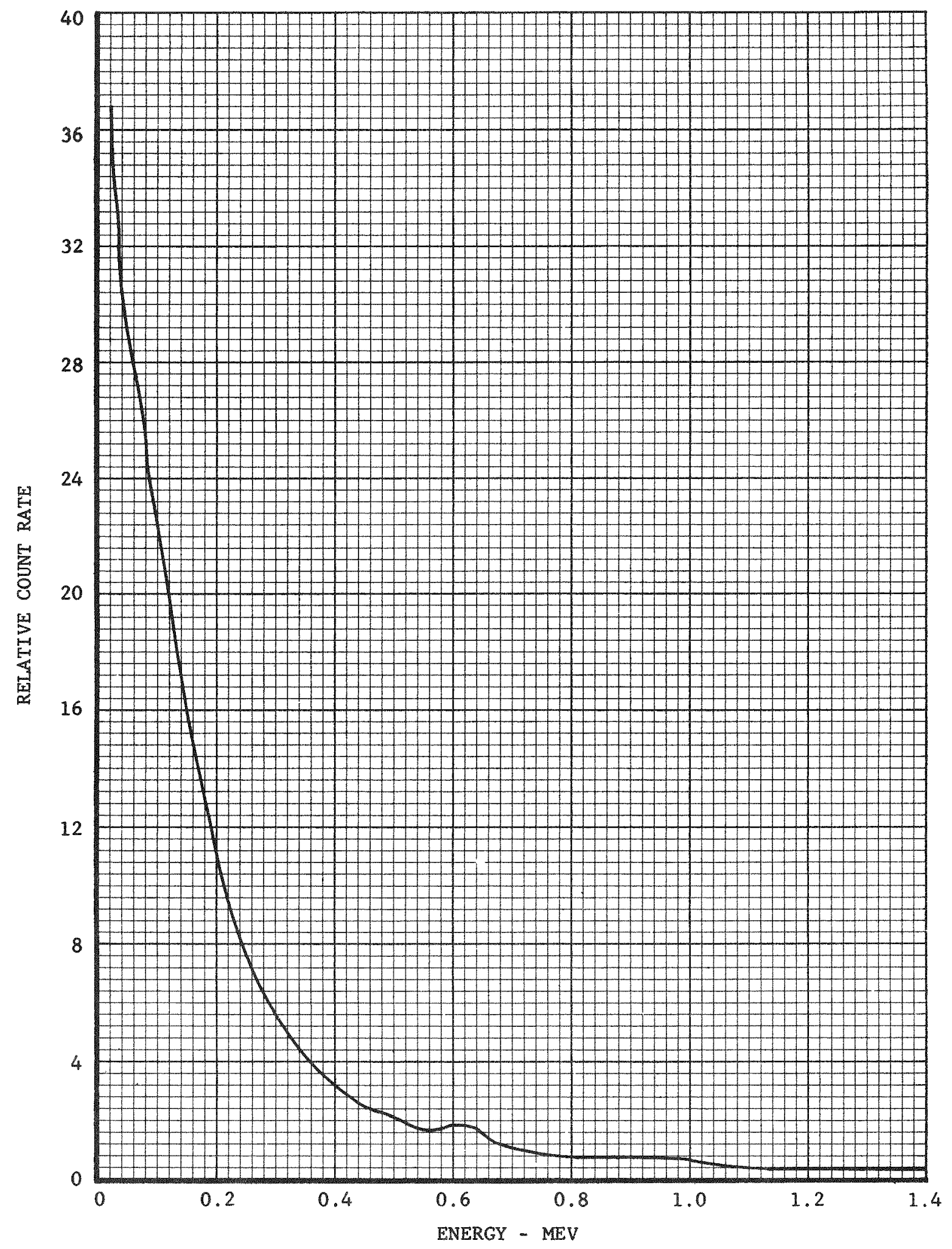

Fig. 3.4-Pulse-height distribution at position B from 196 -curie $\mathrm{CO}^{60}$ source. 


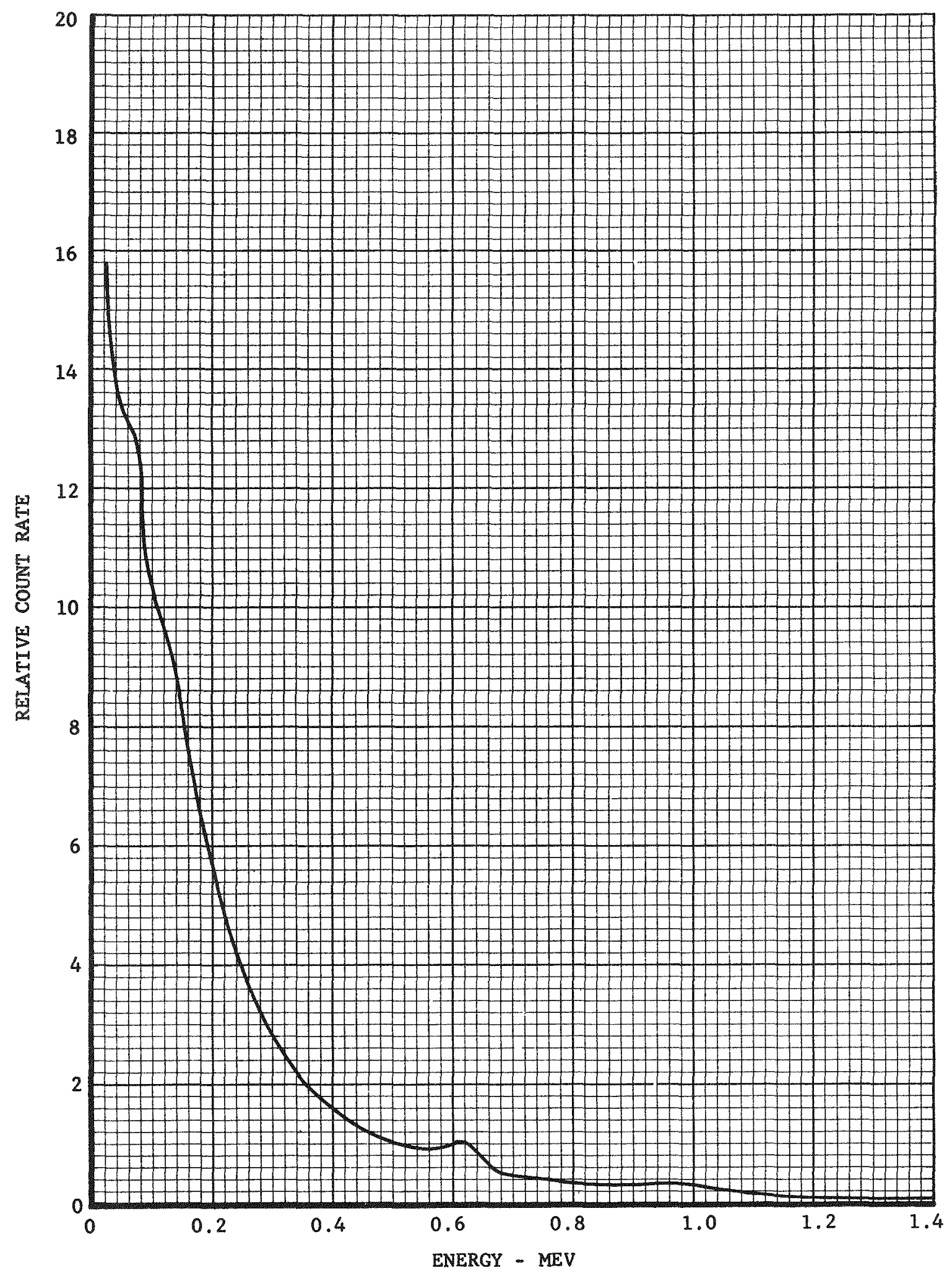

Fig. 3.5-Pulse-height distribution at position $\mathrm{B}$ from 16.3-curie $\mathrm{Co}^{60}$ source. 


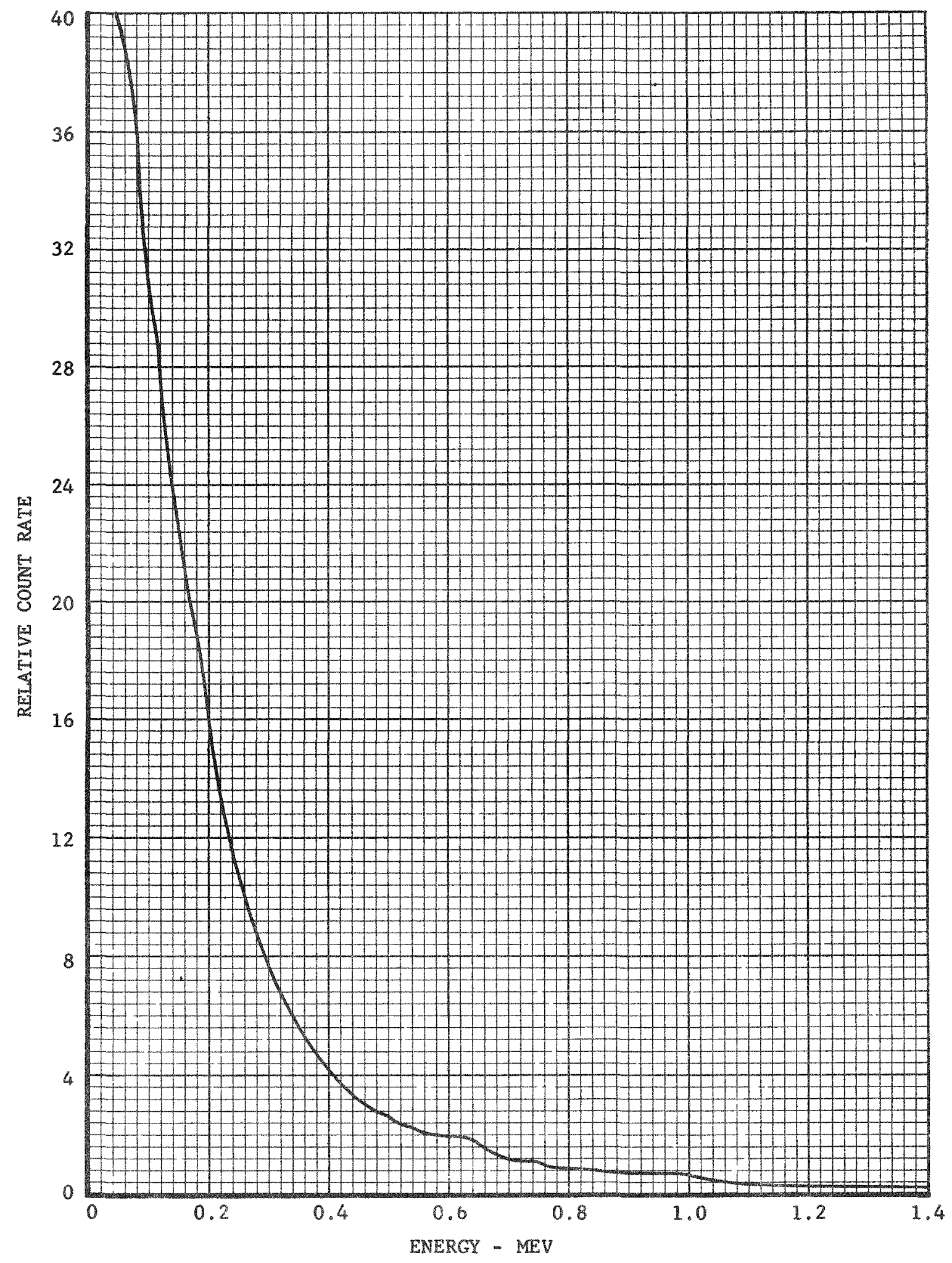

Fig. 3.0-Pulse-height distribution at position $\mathrm{C}$ fron 16.3 -curie $\mathrm{C} \mathrm{O}^{60}$ source. 


\section{Chapter 4}

\section{ANALYSIS AND CONCLUSIONS}

\subsection{GENERAL}

The protection factor, P.F., at any point is defined as the ratio of the exposure dose rate, $\mathrm{D}_{\infty}, 3 \mathrm{ft}$ above a smooth infinite plane uniformly contaminated with a radioactive material to the dose rate, $D$, inside the structure at the point in question when the structure (roof) and ground are covered by the same source distribution. Accordingly,

$$
\text { P.F. }=\frac{D_{\infty}}{D}
$$

Thus, a protection factor is a number indicating the protective value afforded by a structure; it provides a measure of how much less dose would be experienced inside the structure than outside in an unprotected area of the same radiation concentration.

To measure a protection factor with accuracy would require the simulation of fallout radiation on the structure and on the ground surrounding the structure out to an infinite distance. Since this is impractical, simulation in this experiment was limited to the immediate vicinity of the shelter. Fallout radiation was simulated directly over the shelter and on the ground outside out to about $15 \mathrm{ft}$ from the edge of the shelter. The contribution from beyond the measurement area was not considered in determining the protection factors. This contribution may decrease the factor in the entranceways slightly but should not appreciably affect those inside the shelter proper.

Data taken during the experiment were corrected for leakage, temperature, pressure, and calibration. The corrected data were then normalized to milliroentgens per hour per millicurie per square foot by multiplying the true doses $D_{t}$ (in milliroentgens) by the area $A$ (in square feet) over which the tubing was distributed and dividing by the source strength $S$ (in millicuries) and the exposure time $\mathrm{T}$ (in hours). Accordingly,

$$
\text { Normalized data }=\frac{D_{t} A}{T S}
$$

The protection factors were then obtained by dividing these normalized dose rates into the dose rate at a height of $3 \mathrm{ft}$ above a smooth infinite plane of $\mathrm{Co}^{60}$ radiation uniformly contaminated to $1 \mathrm{mc} / \mathrm{sq} \mathrm{ft}$. This total infinite-plane dose rate has been evaluated in the literature $\mathrm{e}^{1-4}$ and is estimated to be $500 \mathrm{mr} / \mathrm{hr}$.

The use of $\mathrm{Co}^{60}$ in simulating fallout radiation for shielding factors has been discussed in the literature. ${ }^{3}$ The protection factors for fission products and $\mathrm{Co}^{60}$ gamma radiation should compare to within 10 per cent. ${ }^{2}$ 


\subsection{PROTECTION FACTORS}

The protection factors were calculated according to the method presented in Sec. 4.1 ; the values for each detector position shown in Fig. 2.18 are given in Table 4.1. These factors plotted on a shelter floor plan appear in Fig. 4.1.

In general, the results indicate that the protection factor is approximately 5000 in the center of the shelter, increasing to 10,000 to 15,000 along the sides, and decreasing to about 3000 near the ends. Directly below the vents, the protection factor is approximately 2500 at the 3 -ft level. The vent opening affects the protection factor only in a small area (less than 4 -ft in diameter) directly below.

The protection factors were slightly more at the $1-\mathrm{ft}$ level and slightly less at the 5 - and 7-ft levels, except directly below the vents and near the ends of the shelter.

The reason for the rather high protection factors is the existence of an earth cover completely over the shelter, with a minimum thickness of $21 \mathrm{in}$. (measured at one point) on the top and increasing from 5 to $7 \mathrm{ft}$ on the sides. In addition, the soil was relatively water soaked at the time of the test.

The protection factors tended to differ from point to point throughout the shelter, undoubtedly as a result of variations in the thickness of the earth cover. For instance, the area along the side and rear appeared to have a deeper than normal cover, and a high factor of 17,000 was noted at that point.

\subsection{ENERGY MEASUREMENTS}

Considerable scattering and resultant dose build-up occurs when a high-energy gamma flux is attenuated by a large thickness of material. For example, the dose build-up factor in 12 in. of concrete for an isotropic point source of $1-\mathrm{Mev}$ incident gamma rays is about 8 (Gladys White, Report NBS-1003). This means that 7 times as much dose results from scattered gammas (less than $1 \mathrm{Mev}$ ) as from gammas of the original 1-Mev energy.

Therefore, the energy spectrum of the radiation entering the shelter was expected to differ considerably from the spectrum normally associated with $\mathrm{Co}^{60}$.

The relative count rate rapidly increased at energies less than $100 \mathrm{kev}$ (Fig. 3.1). Crystal assembly and associated analyzer characteristics were such that pulse pile-up from excessive rates caused erroneous counts to be registered in the energy range from 0 to $100 \mathrm{kev}$. As a result, no quantitative analysis of the spectrum in this energy range can be made.

A slight peak at about $630 \mathrm{kev}$ appears in all the curves. After the experiment it was found that the emitter-follower unit in the preamplifier had a faulty transistor, which caused excessive shortening of the output pulse. This resulted in the linear amplifier's producing an erroneous peak at about $630 \mathrm{kev}$.

Figures 3.3 through 3.6 indicate that a major part of the radiation entering the shelter was degraded; it appeared to be considerably smaller than the 1.17- and 1.33-Mev energy peaks as sociated with $\mathrm{Co}^{60}$. In fact, no $\mathrm{Co}^{60}$ peaks were evident in any of the curves.

A quantitative analysis cannot be given because of two factors: (1) crystal efficiency was not known and (2) the analyzer was rate sensitive. That is, if the gamma flux is too high, the analyzer cannot accurately process all the pulses, and erroneous counts tend to register in the lower channels.

Calculation of the maximum dose rate at all positions (A, B, and $C$ in Fig. 2.18) indicates that it may have exceeded the limit for proper analyzer counting action, even when the 16.3curie source was used. However, the shapes of the curves in Fig. 3.3 through 3.6 are essentially the same, with no noticeable difference between sources or positions.

These results definitely show that, with the shielding used, there is a large build-up of scattered gamma rays of greatly reduced average energy. However, the difficulties of proper analyzer operation under the probable high-flux field conditions limit an accurate quantitative analysis of the data. 


\subsection{DISCUSSION AND GENERAL CONCLUSIONS}

Accurate prediction of a fallout protection factor cannot be made easily because of the many unpredictable factors associated with a fallout situation. These unpredictable factors include the existence of nonuniformly contaminated areas and accumulation of fallout in entranceways. In addition, theoretical calculations become intricate and complicated when consideration is given to the existence of different shielding materials, ground contours, and complex shielding geometry. The protection factors determined during this experiment are based on simulation of a uniform fallout field. These values should represent good approximations of the real fallout protection factor since fallout, under idealized conditions, is uniformly deposited over large areas.

The protection factors were determined from the simulation of fallout radiation on and immediately surrounding the shelter. The contribution from beyond the area simulated would be small compared to the contribution from directly above the shelter. Consideration of the far-field contribution should not appreciably affect the values of the protection factors in the shelter proper.

In general, the shelter offers excellent protection from fallout radiation. The dose rate inside should be from 5000 to 15,000 times less than the dose rate $3 \mathrm{ft}$ above the ground in an unprotected area, assuming the same source concentration. Variations in earth-cover thickness undoubtedly account for the different protection factors noted throughout.

The energy measurements demonstrated conclusively that there was a large build-up of scattered gamma rays of greatly reduced average energy with the shielding used. An accurate quantitative analysis of the data is, however, limited owing to the problems involved in proper analyzer operation under the probable high-flux field conditions.

Complete health physics procedures were followed during the experiment according to the radiological safety plan given in Appendix A. Maximum exposure to project personnel, as read by pocket ionization chambers, was less than $15 \mathrm{mr}$. Maximum exposure to supporting personnel was undetectable (less than $2 \mathrm{mr}$ by pocket chambers).

\section{REFERENCES}

1. J. A. Auxier et al., Experimental Evaluation of the Radiation Protection Afforded by Residential Structures Against Distributed Sources, USAEC Report CEX-58.1, January 1959.

2. J. A. Auxier and T. D. Strickler, Experimental Evaluation of the Radiation Protection Afforded by Typical Oak Ridge Homes Against Distributed Sources, USAEC Report CEX-59.13, April 1960.

3. Charles Eisenhauer, Analysis of Experiments on Light Residential Structures with Distributed $\mathrm{Co}^{60}$ Sources, Report NBS-6539, National Bureau of Standards, October, 1959.

4. J. H. Hubbell, Dose Due to Distributed Gamma-ray Sources, Report NBS-4928, National Bureau of Standards, November 1956. (Official Use Only). 
Table 4.1-PROTECTION FACTORS AT POSITIONS IN THE SHELTER

\begin{tabular}{|c|c|c|c|c|c|c|c|c|c|}
\hline \multirow[b]{2}{*}{ Position } & \multicolumn{4}{|c|}{ Protection factor } & \multirow[b]{2}{*}{ Position } & \multicolumn{4}{|c|}{ Protection factor } \\
\hline & At $1 \mathrm{ft}$ & At $3 \mathrm{ft}$ & At $5 \mathrm{ft}$ & At $7 \mathrm{ft}$ & & At $1 \mathrm{ft}$ & At $3 \mathrm{ft}$ & At $5 \mathrm{ft}$ & At $7 \mathrm{ft}$ \\
\hline 1 & & 240 & & & 21 & & 5000 & 4700 & 4300 \\
\hline 2 & & 830 & & & 22 & & 7200 & 7000 & \\
\hline 3 & & 1400 & & & 23 & 13000 & 15000 & & \\
\hline 4 & 5500 & 3400 & & & 24 & & 13000 & & \\
\hline 5 & & 2400 & 1600 & & 25 & & 7000 & 6200 & \\
\hline 6 & & 2700 & 1900 & 1800 & 26 & & 5300 & 4900 & 4800 \\
\hline 7 & & 2500 & 1700 & & 27 & & 6200 & 6000 & \\
\hline 8 & 7200 & 5900 & & & 28 & & 17000 & & \\
\hline 9 & & 8600 & & & 29 & & 15000 & & \\
\hline 10 & & 4200 & 3000 & & 30 & & 5100 & 5000 & \\
\hline 11 & & 3500 & 3200 & 3300 & 31 & & 4200 & 4300 & 4600 \\
\hline 12 & & 4500 & 4400 & & 32 & & 6300 & 7200 & \\
\hline 13 & & 9000 & & & 33 & & 12000 & & \\
\hline 14 & & 11000 & & & 34 & 11000 & 12000 & & \\
\hline 15 & & 5500 & 5500 & & 35 & & 5400 & 5600 & \\
\hline 16 & & 4500 & 4100 & 4100 & 36 & & 2800 & 2200 & 1900 \\
\hline 17 & & 5800 & 5700 & & 37 & & 2400 & 1600 & \\
\hline 18 & & 13000 & & & 38 & 8600 & 6000 & & \\
\hline 19 & 13000 & 13000 & & & 39 & & 410 & & \\
\hline \multirow[t]{5}{*}{20} & & 6200 & 6200 & & 40 & & 29 & & \\
\hline & & & & \multicolumn{4}{|c|}{ Protection factor } & & \\
\hline & & \multicolumn{2}{|c|}{ Position } & $\overline{\text { At } 1 \mathrm{ft}}$ & At $3 \mathrm{ft}$ & At $5 \mathrm{ft}$ & At $7 \mathrm{ft}$ & & \\
\hline & \multirow{2}{*}{\multicolumn{3}{|c|}{$\begin{array}{l}\text { Below vent } \\
21 \text { in. from } \\
\text { center of vent }\end{array}$}} & & 2400 & 1900 & 1100 & & \\
\hline & & & & & 3700 & 3500 & 3500 & & \\
\hline
\end{tabular}




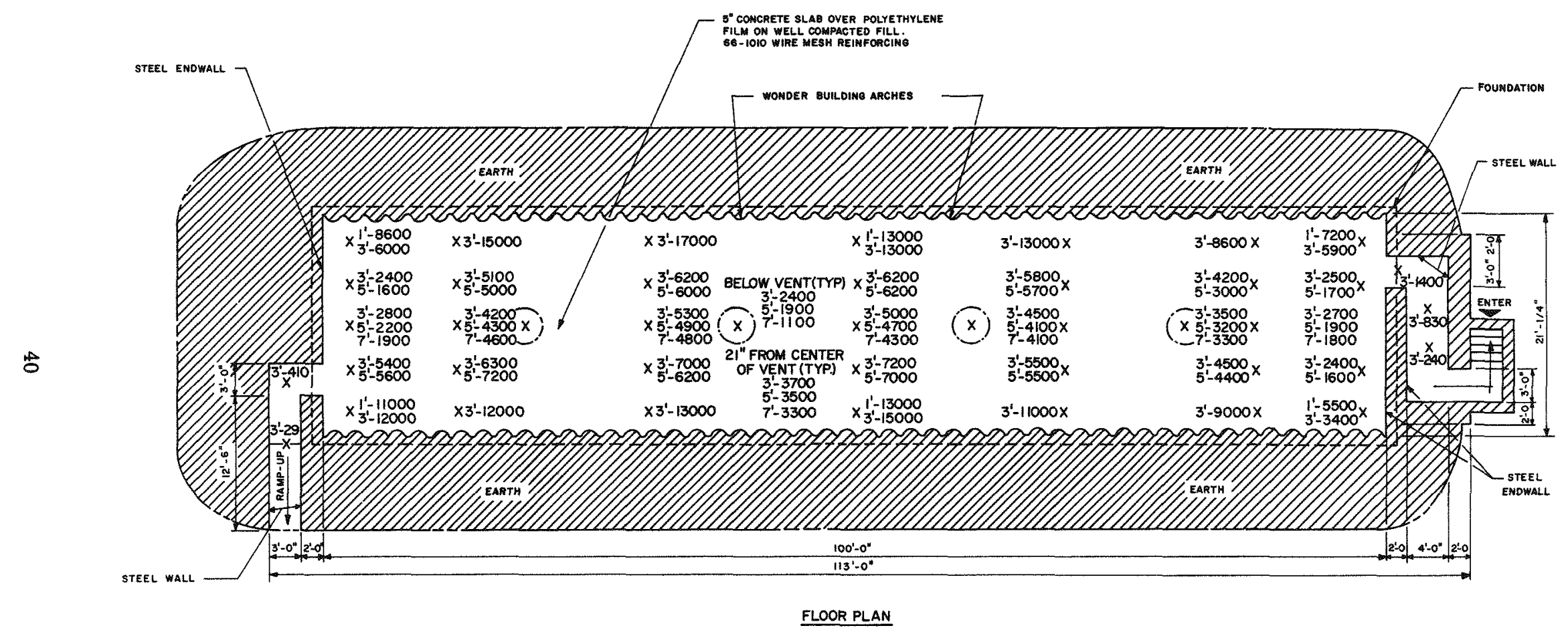

Fig. 4.1-Protection factors plotted on floor plan at different heights above floor. 


\section{Appendix A}

\section{RADIOLOGICAL-SAFETY OPERATIONS}

This Appendix describes the radiation-safety operations carried out during the experimental survey of the earth-covered fallout shelter. The test was performed at night with minimum inconvenience and disruption in the normal activities of others in the area. No unusual incidents occurred, and the measurements were safely completed within the radiological-safety criteria established.

The day before the test, a radiological-safety plan was formulated. In general, this plan consisted in establishing restricted areas, placing radiation and road-block signs, issuing film badges and pocket chambers to appropriate personnel, and checking the test area continuously for unauthorized personnel during actual exposure.

Radiation-safety responsibility was shared by the local officials and the contracting agency performing the test (EG\&G). A Radiological-safety Officer was appointed from each of the organizations. These officers were responsible for the safety of all personnel directly or indirectly associated with the test.

Responsibilities of those conducting the survey included the following:

1. Ensuring proper use and storage of all sources used

2. Issuing of film badges and pocket chambers

3. Reading of all film badges and pocket chambers

4. Ensuring that tests were started only after (1) a local official had reported that a restricted area had been established, that road blocks were set up and manned, and that the mobile patrol was in operation; and (2) that all buildings and the limited-access area had been visually inspected and no unauthorized personnel were present

5. Monitoring outlying security posts and other designated areas during the actual exposure

6. Monitoring the movement and physical location of all personnel within the restricted area during the radiation exposure

7. Being prepared for emergency radiological procedures

8. Maintaining an emergency operating plan

9. Notifying local representatives when the exposure was completed and the source was properly stored

The responsibility of the local authorities included the following:

1. Setting up and maintaining an outer-perimeter limited-access area from 11:00 p.m. October 14, until the test was finished and source secured

2. Limiting unauthorized access into the area adjacent to the shelter

3. Performing final visual inspection of all buildings, rooms, and areas within the enclosure to ensure that the premises had been completely evacuated

4. Moving the local Duty Officer to a nearby building prior to the exercise

5. Setting up communications between the control truck and the duty office 
6. Making reports to the local Radiological-Safety Officer (1) that the limited access area had been established and manned and (2) that the restricted area had been visually inspected and that all unauthorized personnel had been evacuated

7. Reporting any unauthorized personnel in the limited-access area

8. Collecting and returning all film badges and pocket chambers issued to appropriate personnel

Complete health-physics procedures were followed during the experiment. Maximum exposure to project personnel as read by pocket chambers was less than $15 \mathrm{mr}$. Maximum exposure to all other personnel was undetectable (less than $2 \mathrm{mr}$ by pocket chamber). 


\section{Appendix B}

\section{SAMPLE OF DATA, ANALYSIS, AND EVALUATION}

Table B.1 presents a sample of the data from which protection factors were calculated. Reference is made to Chap. 4 in the main body of the report for amplification.

The protection factors, also shown in the table, were found by dividing the infinite-plane dose rate $(500 \mathrm{mr} / \mathrm{hr}$ ) by the normalized shelter dose rate (column 6 ).

Table B.1-CORRECTION AND NORMALIZATION OF DATA

\begin{tabular}{rcccccc}
\hline Position & $\begin{array}{c}\text { Average } \\
\text { reading, } \\
\mathrm{mr}\end{array}$ & $\begin{array}{c}\text { Corr. for } \\
\text { background, } \\
\mathrm{mr}\end{array}$ & $\begin{array}{c}\text { Corr. for } \\
\text { temp. and pres., } \\
\mathrm{mr}\end{array}$ & $\begin{array}{c}\text { Corr. for } \\
\text { calib., } \\
\mathrm{mr}\end{array}$ & $\begin{array}{c}\text { Normalization, } \\
\mathrm{mr} / \mathrm{hr} / \mathrm{mc} / \mathrm{sq} \mathrm{ft}\end{array}$ & P.F. \\
\hline 9 & 2.2 & 2.1 & 2.2 & 2.5 & 0.058 & 8600 \\
10 & 4.4 & 4.3 & 4.4 & 5.1 & 0.118 & 4200 \\
11 & 5.3 & 5.2 & 5.3 & 6.2 & 0.144 & 3500 \\
12 & 4.1 & 4.0 & 4.1 & 4.8 & 0.111 & 4500 \\
\hline
\end{tabular}




\section{CIVIL EFFECTS TEST OPERATIONS REPORT SERIES (CEX)}

Through its Division of Biology and Medicine and Civil Effects Test Operations Office, the Atomic Energy Commission conducts certain technical tests, exercises, surveys, and research directed primarily toward practical applications of nuclear effects information and toward encouraging better technical, professional, and public understanding and utilization of the vast body of facts useful in the design of countermeasures against weapons effects. The activities carried out in these studies do not require nuclear detonations.

A complete listing of all the studies now underway is impossible in the space available here. However, the following is a list of all reports available from studies that have been completed. All reports listed are available from the Office of Technical Services, Department of Commerce, Washington 25, D. C., at the prices indicated.

CEX-57.1 The Radiological Assessment and Recovery of Contaminated (\$0.75) Areas, Carl F. Miller, September 1960.

CEX-58.1 Experimental Evaluation of the Radiation Protection Afforded by (\$2.75) Residential Structures Against Distributed Sources, J. A. Auxier, J. O. Buchanan, C. Eisenhauer, and H. E. Menker, January 1959.

CEX-58.2 The Scattering of Thermal Radiation into Open Underground

(\$0.75) Shelters, T. P. Davis, N. D. Miller, T. S. Ely, J. A. Basso, and H. E. Pearse, October 1959 .

CEX-58.7 AEC Group Shelter. AEC Facilities Division, Holmes \& Narver, (\$0.50) Inc., June 1960.

CEX-58.8 Comparative Nuclear Effects of Biomedical Interest, Clayton S. (\$1.00) White, I. Gerald Bowen, Donald R. Richmond, and Robert L. Corsbie, January 1961.

CEX-58.9 A Model Designed to Predict the Motion of Objects Translated by

(\$1.25) Classical Blast Waves, I. Gerald Bowen, Ray W. Albright, E. Royce Fletcher, and Clayton S. White, June 1961.

CEX-59.1 An Experimental Evaluation of the Radiation Protection Afforded

(\$0.60) by a Large Modern Concrete Office Building, J. F. Batter, Jr., A. L. Kaplan, and E. T. Clarke, January 1960.

CEX-59.4 Aerial Radiological Monitoring System. 1. Theoretical Analysis,

(\$1.25) Design, and Operation of a Revised System, R. F. Merian, J. G. Lackey, and J. E. Hand, February 1961.

CEX-59.7C Methods and Techniques of Fallout Studies Using a Particulate

(\$0.50) Simulant, William Lee and Henry Borella, February 1962.

CEX-59.13 Experimental Evaluation of the Radiation Protection Afforded by

(\$0.50) Typical Oak Ridge Homes Against Distributed Sources, T. D. Strickler and J. A. Auxier, April 1960.

CEX-59.14 Determinations of Aerodynamic-drag Parameters of Small Irregular

(\$1.75) Objects by Means of Drop Tests, E. P. Fletcher, R. W. Albright, V. C. Goldizen, and I. G. Bowen, October 1961.

CEX-60.1 Evaluation of the Fallout Protection Afforded by Brookhaven

(\$1.75) National Laboratory Medical Research Center, H. Borella, Z. Burson, and J. Jacovitch, February 1961.

CEX-62.01 Technical Concept-Operation Bren, J. A. Auxier, F. W.

(\$0.50) Sanders, F. F. Haywood, J. H. Thorngate, and J. S. Cheka, January 1962 .

CEX 60.5 Experimental Evaluation of the Fallout-radiation Protection

( $\$ 0.50)$ Afforded by a Southwestern Residence, Z. Burson, D. Parry, and H. Borella, February 1962. 